\title{
Examination of Different Learning Conditions in the Testing Effect: Example of Safe Internet Use \\ Beyza UÇAR*a ${ }^{*}$, Yasemin DEMIRASLAN ÇEVIK ${ }^{\mathrm{b}}$
}

\begin{tabular}{l} 
Article Info \\
\hline DOI: $10.14686 /$ buefad.322792 \\
\hline Article History: \\
Received $\quad 20.06 .2017$ \\
Revised $\quad 16.01 .2018$ \\
Accepted $\quad 30.01 .2018$ \\
\hline Keywords: \\
Testing Effect, \\
Safe internet use, \\
Different learning conditions in \\
test effect \\
\hline Article Type: \\
Research article \\
\hline
\end{tabular}

\begin{abstract}
Tests in educational setting are often seen as an assessment tool. However, in the field of psychology, memory related studies have shown that being tested affects recall in a positive way. Studying on a material as testing rather than studying on it many times helps better to remember the information in the material. This phenomenon is called Testing Effect. It is stated in the literature that using testing effect in the field of education may have positive result. It is thought that one of the important skills that should be gained to learners is the Safe Internet Usage. The aim of this study is to examine whether the different learning conditions (StudyStudy-Test, Study-Test-Test, Study-Study-Study-Test and Study-Test-Test-Test) are influential for middle school students to learn the topic of Safe Internet Use. The research results show that different learning conditions have an effect on the group's short-term retention performance but not on long term retention.
\end{abstract}

\section{Sınama Etkisinde Farklı Öğrenme Koşullarının İncelenmesi: Güvenli İnternet Kullanımı Konusu Örneği}

\begin{tabular}{|c|c|}
\hline \multicolumn{2}{|c|}{ Makale Bilgisi } \\
\hline \multicolumn{2}{|c|}{ DOI: 10.14686/buefad.322792 } \\
\hline \multicolumn{2}{|c|}{ Makale Geçmişi: } \\
\hline Geliş & 20.06 .2017 \\
\hline Düzeltme & 16.01 .2018 \\
\hline Kabul & 30.01 .2018 \\
\hline \multicolumn{2}{|c|}{$\begin{array}{l}\text { Anahtar Kelimeler: } \\
\text { Sınama Etkisi, } \\
\text { Güvenli internet kullanımı, } \\
\text { Sınama etkisinde farklı öğrenme } \\
\text { koşulları. }\end{array}$} \\
\hline \multicolumn{2}{|c|}{$\begin{array}{l}\text { Makale Türü: } \\
\text { Arastırma makalesi }\end{array}$} \\
\hline
\end{tabular}

$\ddot{O} \mathbf{z}$

Eğitim ortamında testler genellikle bir değerlendirme aracı olarak görülmektedir. Ancak psikoloji alanında bellek ile ilgili yürütülen çalışmalar göstermiştir ki sınanmak aynı zamanda hatırlamayı da olumlu yönde etkilemektedir. Bir materyale defalarca çalışıp sonrasında sınanmaktansa, bir kere çalışıp birçok kez sınanmak materyaldeki bilgilerin daha iyi hatırlanmasına yardımcı olmaktadır. $\mathrm{Bu}$ durum Sınama Etkisi olarak adlandırılmaktadır. Alan yazında sınama etkisinin eğitim amaçlı kullanımının da olumlu sonuçlar doğurabileceği belirtilmektedir. Günümüzde öğrenenlere kazandırılması gereken önemli becerilerden birinin de Güvenli İnternet Kullanımı konusu olduğu düşünülmektedir. $\mathrm{Bu}$ araştırma kapsamında ortaokul öğrencilerinin Güvenli İnternet Kullanımı konusunu öğrenmelerinde farklı öğrenme koşularının (Çalış-Çalış-Sına, Çalış-Sına-Sına, Çalış-Çalış-Çalış-Sına ve Çalış-Sına-Sına-Sına) öğrenenlerin hatırlama performansları üzerine etkisi araştırılmıştır. Araştırma sonucunda farklı öğrenme koșullarının grupların kısa süreli hatırlama performansı üzerinde etkisi olduğu ancak uzun süreli hatırlama performansları üzerinde istatistiksel açıdan anlamlı bir etkisi bulunamamıștır.

\footnotetext{
*Corresponding Author: beyzau10@gmail.com

${ }^{a}$ Graduate Student, Department of Computer Education and Instructional Technology, Hacettepe University, Ankara/Turkey, https://orcid.org/0000-0003-1979-6312

b Assoc. Prof. Dr., Department of Computer Education and Instructional Technology, Hacettepe University, Ankara/Turkey, https://orcid.org/0000-0002-5160-4766
} 


\section{Introduction}

The main purpose of educational activities is to achieve the specified goals and to fulfill certain functions (Şişman, 2011). Accordingly, it can be stated that measurement and evaluation activities are of importance in determining the extent to which the specified goals have been achieved and in providing information on the process of education. There are many different tools for measurement such as oral exams, written exams, short answer tests, true-false questions and multiple choice tests to perform the evaluation process in education. Studies on memory indicated that the use of tests positively contributes to the evaluation process as well as the skill of recalling a previously learned material (Darley \& Murdock, 1971; McDaniel, Kowitz, \& Dunay, 1989; Whitten \& Bjork, 1977). This is called testing effect, which is based on the assumption that studying a material once and testing it several times is more effective than testing over re-studying the material in recalling the information related to the material.

On the argument that the testing effect leads to a better retention performance, Terry (2011) came up with three different explanations: (1) Taking a practice test is just another version of studying and offers a more interesting opportunity for restudying compared to simply presenting the material a second time. (2) Answering test questions requires more cognitive efforts than re-reading, (3) Retrieval is better when the mental operations performed during the retrieval match the operations performed during encoding. In this sense, as studying a material by taking a test, is similar to the process of retrieving information from memory, it can be associated with a better retention performance. Roediger, Putnam and Smith (2011, p.4) identified 10 benefits of the testing effect when it is applied as an individual studying strategy in an educational environment or a classroom tactic:

1. The testing effect emphasizing retrieval aids later retention,

2. Testing identifies gaps in knowledge,

3. Testing causes students to learn more from the next study episode,

4. Testing produces a better organization of knowledge,

5. Testing improves transfer of knowledge to new contexts,

6. Testing can facilitate retrieval of material that was not tested,

7. Testing improves metacognitive monitoring,

8. Testing prevents interference from prior material when learning new material,

9. Testing provides feedback to instructors,

10. Frequent testing encourages students to study.

The objective is to ensure that learning activities during the training process are more permanent and of higher quality. Following the findings in the field of experimental psychology that the testing effect has the potential to achieve such objective, many researchers in educational field have studied the testing effect as well. Indeed, these studies examined the effect of feedbacks, different test types and different studying conditions on the emergence of the testing effect. For instance, Agarwal, Karpicke, Kang, Roediger and McDermott (2008) performed a study with university students to investigate the testing effect in conditions that a feedback was provided and not provided in open-book tests where students may use their books and notes during the exam as well as in closedbook tests where students are not allowed to take their books and notes into the exam. The students first studied on prose texts, then either restudied the material or participated in an open-book or a closed-book test in the absence and presence of a feedback. The study concluded that taking either kind of test in the presence of a feedback improved long-term retention compared to conditions where learners restudied the material or took a test in the absence of a feedback. Moreover, it revealed that learners in the open-book test outperformed others in the closedbook test in terms of short-term retention. However, there was no difference between these two groups in terms of long-term retention.

With the intent of examining the effect of tests on long-term retention, Butler and Roediger (2007) carried out a study where university students studied a lecture summary, took a multiple-choice test or took a short answer test. In the study, the correct answer in the form of a feedback was provided to half of the participants who took 
either of the tests. The study showed that the participants who took the short-answer test outperformed others in terms of long-term retention and determined that the participants who studied a lecture summary and took the multiple-choice test demonstrated outperformed those who were not involved in any activity in terms of long-term retention. On the contrary, Agarwal et al. (2008) found that the provision of a feedback did not have any effect on the retention performance of the participants.

Another study by Butler, Karpicke and Roediger (2007) explored how the type and timing of feedback affects learning from multiple-choice tests. In the study, the students were first asked to read passages, ranging between 280-300 words in length. Following that, they took a 6-alternative multiple-choice test on the information in the passages. The students were provided with two different types of feedbacks, one with a correct answer and the other allowing them to keep answering until they find the correct answer. These feedbacks were given immediately for some of the multiple-choice items or with delay for other items. The study found out that there was no difference in terms of the type of the feedback provided in the final test; yet, those provided with a delayed feedback showed better performance than others provided with an immediate feedback.

Larsen, Butler and Roediger (2009) conducted a study with medical residents to investigate the testing effect in learning status epilepticus or myasthenia gravis. The residents first participated in a teaching session on these topics and were divided into two groups. While one group studied a review sheet on status epilepticus and took tests on myasthenia gravis, the other group studied a review sheet on myasthenia gravis and took tests on status epilepticus. During the practice, the residents received feedbacks. The residents took a test after 6 months, which showed that the group involved in repeated testing demonstrated better performance. Similarly, Carpenter, Pashler $\&$ Cepeda (2009) revealed that the group reviewing the facts through testing outperformed others in long-term retention (16 weeks).

To explore the effect of different types of test on retention of information, McDermott et al. (2014) performed a study with secondary and high school students. In the study, one group of the students took multiple-choice and short-answer quizzes and received feedbacks for these quizzes. The other group restudied the subject. The study concluded that the group involved in a retest condition outperformed the group involved in a restudy condition in terms of retention of information. Further, it showed that multiple-choice tests were as effective as short-answer tests for retention. On the contrary, McDaniel, Anderson, Derbish \& Morrisette (2007a) and McDaniel, Roediger $\&$ McDermott (2007b) found out that short-answer tests are more effective than multiple-choice tests in terms of retention of information. In their study on different types of test in the testing effect (true/false, multiple-choice and fill-in-the-blank questions) Atabek Yiğit and Balkan Kıyıcı (2016) reported that true/false tests are more effective and these tests are respectively followed by fill-in-the-blank questions and multiple-choice tests in terms of effectiveness.

Atabek Yigit, Balkan Kiyici and Çetinkaya (2014) carried out a study with prospective science teachers $(\mathrm{n}=98)$ to reveal the role of the testing effect in conditions where a feedback was provided in a learning condition (testing or restudying) supported by different activities (multiple-choice tests, matching tests and worksheets) on the topic of "Naming Compounds" or where the final test was administered in different times (a day later: Short-term and a week later: Long-term retention). The learners took a pre-test containing 100 short-answer questions and were divided into 6 experimental groups (G1, G2, G3, G4, G5 and G6) and 1 control group. After the pre-test, G1 and G3, which were among the four groups involved in testing as a learning condition, were not provided with any feedback; G1 took the final test a day later and G3 took it a week later. G2 and G4 were provided with feedbacks; G2 took the final test a day later and G4 took it a week later. As the two experimental groups involved in restudying as a learning condition, G5 took the final test a day later and G6 took it a week later. The control group was not involved in any activity during the study. The study concluded that the increase in the final test performance of the experimental groups was statistically significant in terms of different types of supporting activities (multiplechoice tests, matching tests and worksheets). Thus, the study argued that regardless of the type of practice (testing or restudying), supporting activities (multiple-choice tests, matching tests and worksheets) have a positive effect on retention of information. However, the comparisons between the groups were not found to be statistically significant in terms of the type of the test, feedback or the implementation of the final test in different times (a day later: Short-term and a week later: Long-term retention).

Roediger and Karpicke (2006b) performed two experiments with university students to examine the retention performance 5 minutes, 2 days and 1 week after in different learning conditions with regards to the testing effect. In the first experiment, the students were divided into two groups as Study-Study and Study-Test and studied the 
material in line with the learning condition. Following that, the groups took a test 5 minutes, 2 days and 1 week after. The study concluded that the study group outperformed the other group in terms of retention performance in the test after 5 minutes. Yet, the test group outperformed the study group in the tests 2 days and 1 week after. In the second experiment, the students were divided into three groups as Study-Study-Study-Study, Study-StudyStudy-Test and Study-Test-Test-Test and studied the material in line with the learning condition. Afterwards, the groups took a test 5 minutes and 1 week after. The study concluded that the group of Study-Study-Study-Study outperformed the other groups in terms of retention performance in the test 5 minutes after, respectively followed by the group of Study-Study-Study-Test and the group of Study-Test-Test-Test. The group of Study-Test-TestTest outperformed the other groups in the test 1 week after, respectively followed by the group of Study-StudyStudy-Test and the group of Study-Study-Study-Study.

Dobson and Perez (2016) conducted a study to explore the effect of spaced learning and one-time learning in relation to the testing effect. In the study, the learners were assigned to one of the following 5 groups: Study-StudyStudy-Study where restudying was performed in 3 different days; Study-Test-Study-Test where restudying and testing was performed in 3 different days; Study-Study-Study-Study-Study-Study where restudying was performed in 2 different days; Study-Test-Study-Test-Study-Test where restudying and testing was performed in 2 different days and Study-Test-Study-Test-Study-Test where restudying and testing was performed at one time. The results of the test performed 1 week after learning showed that the students in the group (Study-Study-Study-Study), where restudying was performed in 3 different days, outperformed others, and this group was respectively followed by the group (Study-Test-Study-Test) where restudying and testing was performed in 3 different days, the group (Study-Study-Study-Study-Study-Study) where restudying was performed in 2 different days, the group (StudyTest-Study-Test-Study-Test) where restudying and testing was performed in 2 different days and the group (StudyTest-Study-Test-Study-Test) where restudying and testing was performed at one time.

Demiraslan Çevik and Çoban (2016) studied the effect of different learning conditions (restudying or testing) on learning the topics of "Digital Property and Cyber Ethics" among pre-service Information Technologies teachers $(n=33)$. In the study, the learners were assigned to one of the two groups as Group 1 (Study-Study-Test) and Group 2 (Study-Test-Test) and participated in a 2-week practice. In the first week, the learners in Group 1 studied the topic of digital property for 10 minutes; were then asked to complete a 2-minute distraction task including multiplications; studied the material for another 10 minutes; completed a 5-minute distraction task including multiplications and took a 10-minute test. Following that, the learners in Group 1 studied the topic of cyber ethics in the same order. The learners in Group 2 studied the topic of digital property for 10 minutes; completed a 2-minute distraction task including multiplications; took a 10-minute test and completed a 5-minute distraction task including multiplications and took a 10-minute test again. Following that, the learners in Group 2 studied the topic of cyber ethics in the same order. In the second week, the learners in both groups took a 10minute final test again. The study concluded that the learners involved in restudying as the learning condition had higher retention levels after the first test (after 5 minutes) whereas the learners involved in testing as the learning condition showed higher retention levels in retention test (after 1 week); yet, the difference was not found to be statistically significant.

It is remarkable that most of the studies in the literature were carried out with university or high-school level students (e.g., Agarwal et al., 2008; Atabek Yigit et al., 2014; Atabek Yiğit \& Balkan Kıyıcı, 2016; Demiraslan Çevik \& Çoban, 2016; McDaniel et al., 2007a; Roediger \& Karpicke, 2006b; Butler \& Roediger, 2007). Moreover, McDaniel et al. (2007b) highlighted the need to carry out more studies with younger students. On the other side, it is notable that the studies on the testing effect in Turkey are few (e.g. Atabek Yigit et al., 2014; Atabek Yiğit \& Balkan Kıyıcı, 2016; Demiraslan Çevik \& Çoban, 2016).

In the studies on the testing effect, the participants generally studied the material and then either restudied the material or took a test (Terry, 2011). The relevant literature has argued that taking more tests has a positive effect and studying more has a negative effect on long-term retention (Roediger \& Karpicke, 2006b). Similarly, Demiraslan Çevik \& Çoban (2016) suggested that increasing the number of tests positively affects the groups, involved in retesting as the learning condition. Yet, it is noteworthy that the studies regarding how different combinations (Study-Study-Final Test, Study-Test-Final Test, Study-Study-Study-Final Test and Study-Test-TestFinal Test) of learning conditions can affect information retention are few in the current educational research (e.g. Roediger \& Karpicke, 2006b). Considering the gaps in the literature, the present study with secondary-school students aims to investigate the effect of different combinations of learning conditions on retention of information. 
Today, one of the important skills that learners should acquire is Safe Internet Use. This study seeks to analyze the testing effect in the topic of Safe Internet Use. The next section presents the relevant literature.

\title{
Safe Internet Use
}

Due to the developments in technology - particularly, in the Information and Communication Technologies (ICT) - including the invention of radio in the early 1920s and the invention of televisions, computers, tablets and smart phones, it can be stated that internet has become an almost indispensable part of our life (Heesen, 2012). As a result, the use of internet has been considerably increasing in educational area, as in many areas in ICT. Further, many countries have started to shape their technological policies in line with the use of internet and to develop various projects (e.g. FATİH project in Turkey) aimed at enhancing the use of ICT in educational environments.

That being said, while the rate of internet use among the individuals aged between 16-74 in Turkey was $41,6 \%$ in 2010, it increased to $61.2 \%$ in 2016 (TÜİK, 2010; TÜंIK, 2016); and, the average age at which the children aged between 06-15 start using internet is 9 (TÜİK, 2013). However, such increase in internet use turned internet into a virtual world where there are many different individuals and risks, and this virtual world creates a risk factor particularly for the children who are not aware of potential threats of internet use (Karakuş, Çağıltay, Kaşıkc1, Kurşun \& Ogan, 2014).

Studies in the literature have claimed that unconscious and excessive internet use reduces satisfaction with life (Köse, 2016) and increases tendency to depression (Morrison \& Gore, 2010) and loneliness (Meral \& Bahar, 2016). Moreover, it is notable that the children in a younger age group are asked to provide their personal information and exposed to risky situations where strangers want to chat with them (Ersoy \& Y1lmaz, 2015). In this regard, many researchers emphasized that it is important to raise awareness among children for safe internet use and to provide education for them (Ersoy \& Yllmaz, 2015; Takemura \& Umino, 2009; Tekin \& Polat, 2014). In their study on the practices for safe internet use in Turkey, Aslan \& Karakuş Yılmaz (2017) reported that these practices are in the form of awareness-raising seminars, activities, awareness and promotion campaigns, printed and visual materials, report line, technical and legal measures. Despite the importance of safe internet use, it is remarkable that studies on the effect of different learning methods in learning safe internet use in Turkey are very few in number (örneğin, Korkmaz \& Esen, 2016). Further, there is no study on the role of the testing effect in learning this topic in the relevant literature.

For that reason, this study aims to analyze the effect of different combinations (Study-Study-Test, StudyTest-Test, Study-Study-Study-Test and Study-Test-Test-Test) of learning conditions (testing or restudying) on the retention performance of secondary-school students in learning the topic of Safe Internet Use and to address the gaps specified in the literature. In line with its purpose, this study seeks to answer the following research questions:

1. How do different learning conditions (Study groups: Group 1: Study-Study-Test and Group 3: StudyStudy-Study-Test, Test groups: Group 2: Study-Test-Test and Group 4: Study-Test-Test-Test) in learning the topic of Safe Internet Use affect the retention performance of learners 5 minutes after?

2. How do different learning conditions in learning the topic of Safe Internet Use affect the retention performance of learners 1 week after?

3. How does the retention performance of learners 5 minutes and 1 week after vary according to different learning conditions in learning the topic of Safe Internet Use?

4. What are the opinions of the learners regarding the learning process?

\begin{abstract}
Method

\section{Research Design}

To explore the effect of different combinations (Study-Study-Test, Study-Test-Test, Study-Study-Study-Test and Study-Test-Test-Test) of learning conditions (testing or restudying) on retention performance in learning the topic of Safe Internet Use, this study employed a mixed research method in which both quantitative and qualitative methods are used. The mixed research method in the study is an explanatory design. In this design, quantitative data are collected and then, to support these data, qualitative data are collected (Büyüköztürk, Kılıç Çakmak, Akgün, Karadeniz \& Demirel, 2013; Fraenkel \& Wallen, 2003). The quantitative dimension of the study employed
\end{abstract}


a quasi-experimental design, which is one of experimental designs. In a quasi-experimental design not the individuals but the groups are randomly assigned. In the qualitative dimension of the study, content analysis method was utilized. Content analysis is a systematic and iterative technique through which some words in a text are summarized into smaller content categories according to codings based on certain rules (Büyüköztürk vd., 2013, p.240).

\section{Study Group}

The research group consisted of 102 students (57 girls and 45 boys) studying in the 6th grade at an elementary school in Hatay in the 2016-2017 academic year. Following the interviews with the course teacher, it was revealed that the learners took the course for the first time and assumed that they did not have any prior knowledge on the topic of Safe Internet Use. The participants were randomly assigned to the research groups. Accordingly, Group 1 (Study-Study-Test) and Group 3 (Study-Study-Study-Test) were restudy groups; Group 2 (Study-Test-Test) and Group 4 (Study-Test-Test-Test) were test groups. There were 23 people in Group 1, 28 people in Group 2, 26 people in Group 3 and 25 people in Group 4.

\section{Data Collection Tools}

The researchers prepared a study material in the form of a booklet for the learners to study the topic of Safe Internet Use. The opinions of Information Technologies (IT) teachers and the course book of Information Technologies and Software were taken into consideration in the preparation of the material. Furthermore, visual elements were used in the design of the material to attract the learners. Two different IT teachers expressed their opinions on the selection of visual elements and the organization of the content in the material. At first, the material included 10 items on what to do and what to pay attention in dangerous situations which the learners may face with while using internet as well as their explanations. Regarding the items in the booklet, tests (Test 1 , Test 2 and Test 3) were developed to have different surface characteristics but same structural characteristics and to include 10 questions designed as a case study (see Appendix 1, Appendix 2 and Appendix 3). A preliminary study was performed with a group of 20 people in the same age group to evaluate the material prepared for the study and to determine the potential errors in the practice. Following the study, formal mistakes and incoherencies in the booklet and exam materials were eliminated. Moreover, the items to be studied by the learners were reduced from 10 to 5 , given the length of the practice and the course process. Similarly, the number of the questions in the test developed in the study was reduced from 10 to 5 . For the selection of 5 items to be studied by the learners, IT teachers were interviewed and in line with their feedbacks, the items which the learners frequently encounter with in everyday life, were selected. In view of the course hour, a period of 10 minutes was specified for the booklet; a period of 2 minutes was set for the distraction task 1 and 2; a period of 5 minutes was set for the distraction task 3 and a period of 10 minutes was determined for the tests.

Test 1 and Test 2 were utilized as study material; Test 3 was used to compare the retention performances shortly after the learning ( 5 minutes) and long after the learning (1 week later). The design of the studies on the testing effect in the literature was taken into consideration to determine the periods to be used for the comparison of the retention performances. The learners were expected to analyze the case study provided and to retention the relevant item in all the three tests. Three different distraction tasks were developed to eliminate a retention effect that may potentially emerge between the materials studied by the learners (see Appendix 4, Appendix 5 and Appendix 6). As the content of the materials used in the conditions of studying and testing is verbal, numerical tasks consisting of four modes of operations were used for distraction.

\section{Data Collection}

The practice was designed to last a total of two weeks. The learners were provided with information on the practice at the beginning of the practice. In the first week, the groups received the materials and tests in line with their learning conditions (testing or restudying). In the first week of the practice, the groups completed the following tasks: (1) Group 1 (Study-Study-Test) studied the topic of Safe Internet Use in the booklet for 10 minutes, completed the distraction task 1 for 2 minutes, studied the material for another 10 minutes, completed the distraction task 3 for 5 minutes and took the Test 3 for 10 minutes; (2) Group 2 (Study-Test-Test) studied the topic of Safe Internet Use in the booklet for 10 minutes, completed the distraction task 1 for 2 minutes, took the Test 1 for 10 minutes, completed the distraction task 3 for 5 minutes and took the Test 3 for 10 minutes; (3) Group 3 (Study-Study-Study-Test) studied the topic of Safe Internet Use in the booklet for 10 minutes, completed the 
distraction task 1 for 2 minutes, studied the material for another 10 minutes, completed the distraction task 2 for 2 minutes, restudied the material for 10 minutes, completed the distraction task 3 for 5 minutes and took the Test 3 for 10 minutes; (4) Group 4 (Study-Test-Test-Test) studied the topic of Safe Internet Use in the booklet for 10 minutes, completed the distraction task 1 for 2 minutes, took the Test 1 for 10 minutes, completed the distraction task 2 for 2 minutes, took the Test 2 for 10 minutes, completed the distraction task 2 for 5 minutes and took the Test 3 for 10 minutes. The booklets and the materials regarding testing (tests and distraction tasks) were collected from the learners at the end of the practice. In the second week, to evaluate the retention performance in the long term, the groups took the Test 3 for 10 minutes and were asked to answer the following question: "In your opinion, how did the studying method that you used affect your learning of the topic of Safe Internet Use? Please explain." Figure 1 indicates the practice in the first week and figure 2 presents the practice in the second week.

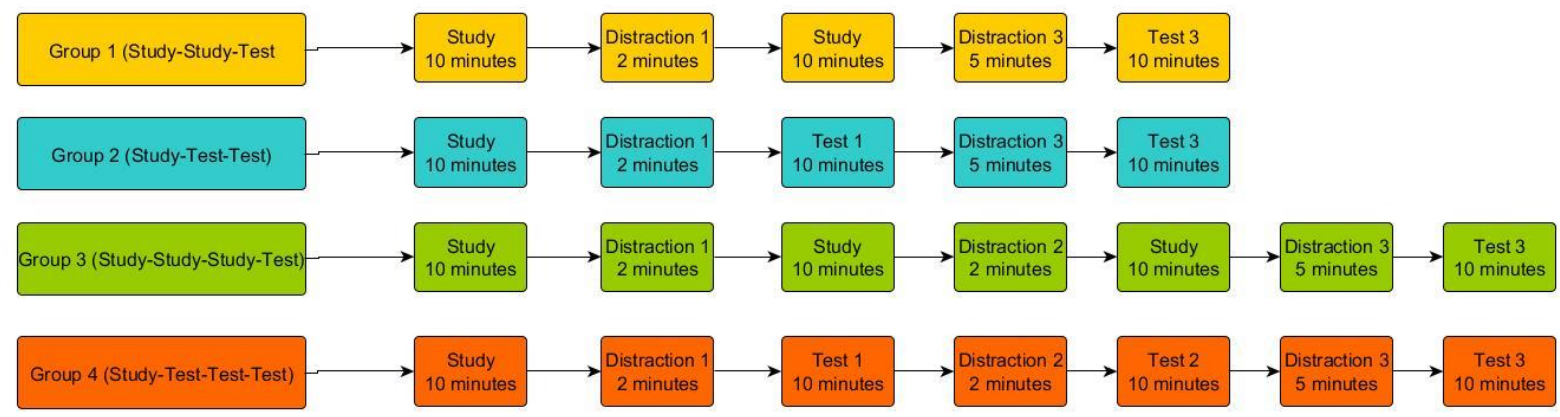

Figure 1. Implementation Process of The First Week

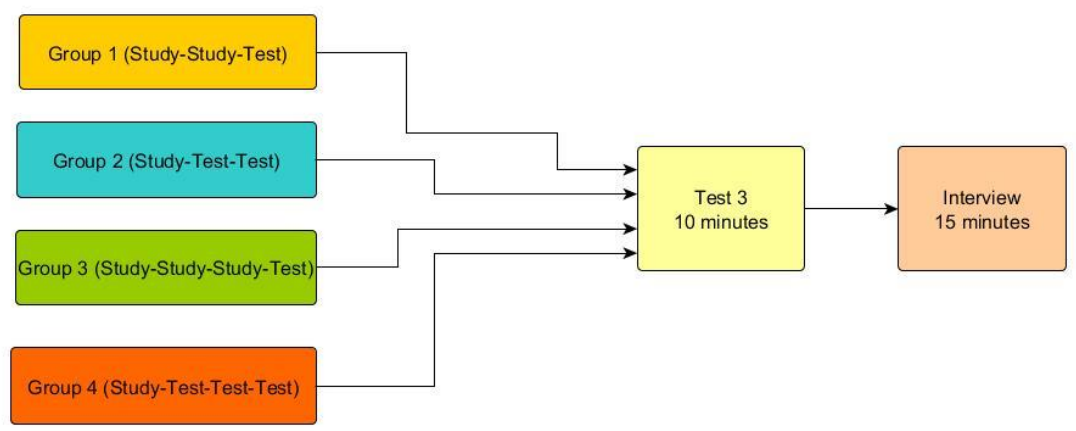

Figure 2. Implementation Process of The Second Week

\section{Data Analysis}

Test 3 was administered to the learners to evaluate the retention performances 5 minutes and 1 week after. The lowest possible score in Test 3 was 0 whereas the highest possible score was 100. A check list consisting of the items, which the learners were expected to retention, was prepared for use in the evaluation of Test 3 . Each item, which was fully recalled by a learner, in the check list was scored as 20 points. The items with two different conditions, such as the item that "Do not share the personal information about yourself or someone else with people you do not know in social media", were scored as 20 points when fully recalled, and as 10 points when partially recalled. The check list is presented in Appendix 7 and a sample evaluation is presented in Appendix 8. The answers of the learners to Test 3 were assessed by two raters (the first one is the author and the second one is an information technologies and software teacher) and the Cohen's Kappa coefficient was calculated for inter-rater agreement. As result, the Cohen's Kappa coefficient was found to be 0.77. It is reported in the literature that a value of Cohen's Kappa coefficient at and over 0.75 refers to excellent agreement; a value of Cohen's Kappa coefficient between 0.40 and 0.75 signifies good agreement and a value of Cohen's Kappa coefficient at and below 0.40 indicates poor agreement (Krippendorff, 1980). Accordingly, it can be stated that there was an excellent agreement between the raters.

The analyses were performed by means of SPSS program. The significance level was set at 0.05 for the interpretation of the data. In the literature, it is reported that One Simple Kolmogrov Smirnov can be used to test 
the normality of the data (Mirabella, 2006). The One Simple Kolmogrov Smirnov test was utilized in the present study to test the normality of the data on the retention performance of the groups 5 minutes after and 1 week after. Table 1 presents the values for the results of the analysis.

Table 1. The Results of the One Sample Kolmogorov Smirnov Test of Groups' Performance of 5 Minutes After and 1 Week After

\begin{tabular}{|c|c|c|c|c|c|}
\hline & & $\begin{array}{c}\text { Group 1 } \\
\text { (Study-Study- } \\
\text { Test) }\end{array}$ & $\begin{array}{c}\text { Group 2 } \\
\text { (Study-Test- } \\
\text { Test) }\end{array}$ & $\begin{array}{c}\text { Group } 3 \text { (Study } \\
\text { Study-Study- } \\
\text { Test) }\end{array}$ & $\begin{array}{l}\text { Group } 4 \text { (Study- } \\
\text { Test-Test-Test) }\end{array}$ \\
\hline \multirow{4}{*}{$\begin{array}{l}5 \text { Minutes } \\
\text { After }\end{array}$} & Mean & 25,22 & 36,07 & 26,92 & 44,00 \\
\hline & sd & 22,937 & 28,589 & 24,620 & 27,080 \\
\hline & Kolmogorov-Smirnov Z & ,953 & 823 & 1,153 & ,794 \\
\hline & Asymp. Sig. (p) &, $324 *$ &, $507 *$ &, $140^{*}$ &, $555^{*}$ \\
\hline \multirow{4}{*}{$\begin{array}{l}1 \text { Week } \\
\text { After }\end{array}$} & Mean & 30,00 & 33,93 & 30,77 & 42,40 \\
\hline & sd & 20,449 & 27,126 & 24,645 & 26,969 \\
\hline & Kolmogorov-Smirnov Z & ,938 &, 576 & 1,058 & ,677 \\
\hline & Asymp. Sig. (p) &, $342^{*}$ & $895^{*}$ &, $213^{*}$ &, $749 *$ \\
\hline
\end{tabular}

As seen in Table 1, the data on the retention performance of the groups 5 minutes after and 1 week after were normally distributed $(\mathrm{p}>0.05)$. As the normality assumption was met, parametric tests were used in the research process. Accordingly, ANOVA was performed to compare the retention performance of the groups 5 minutes after the implementation of their learning condition (restudying or testing); ANCOVA was conducted to compare the retention performance of the groups 1 week after and a paired sample $t$ test was carried out to analyze how the performance of the groups 5 minutes after and 1 week after varied. The homogeneity of variances was checked for ANOVA and it was found that the variances were homogeneous $(\mathrm{p}=0.568>0.05)$. The homogeneity of variances and regression slopes within the groups were checked for ANCOVA. It was revealed that the variances of the groups were homogeneous $(\mathrm{p}=0.257>0.05)$ and the regression slopes within the groups were the same $(\mathrm{p}=0.971>0.05)$.

A content analysis was performed in order to evaluate the opinions of the learners on the process. The answers of the students to the interview questions were revised and the important statements were underlined to identify key themes and sub-themes. Thus, the answers of the learners, the effect of the learning condition on motivation and participation and the effect of the learning condition on learning performance were organized under key themes while positive/negative opinions were grouped under sub-themes. The data on the opinions of each group were analysed by means of this coding method.

\section{Findings}

\section{Findings on the First Research Problem}

The first research problem is as follows: "How do different learning conditions (Study groups: Group 1: StudyStudy-Test and Group 3: Study-Study-Study-Test, Test groups: Group 2: Study-Test-Test and Group 4: StudyTest-Test-Test) in learning the topic of Safe Internet Use affect the retention performance of learners 5 minutes after?" Figure 3 shows the distribution of the retention performances of the learners on the topic of Safe Internet Use according to the groups; Table 2 presents the results of the analysis for the retention performances of the learners 5 minutes after. 


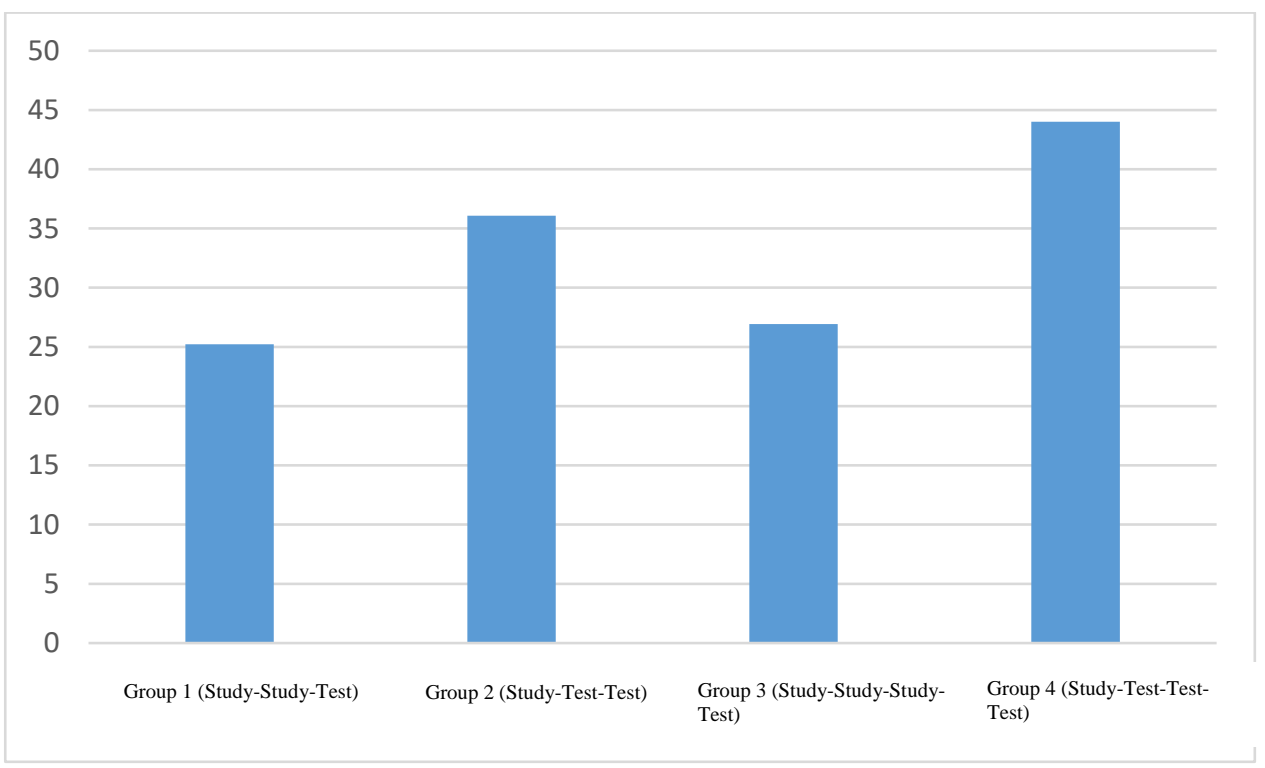

Figure 3. Distribution of Groups' 5 Minutes After Retention Performance

As observed in the graph in Figure 1, the group with the highest retention performance 5 minutes after was the group which took the most tests (Group $4(\mathrm{M}=44)$ ), which was followed by the group which took two tests (Group $2(M=36,07))$, the group which studied most (Group $3(M=26,92))$, and the group which studied least (Group 1 $(\mathrm{M}=25,22))$. ANOVA was performed in order to identify any significant difference between the retention performances of the groups.

Table 2. ANOVA Results of Groups' 5-Minutes After Retention Performance

\begin{tabular}{lccccc}
\hline & $\begin{array}{c}\text { Sum of } \\
\text { Squares }\end{array}$ & df & $\begin{array}{c}\text { Mean } \\
\text { Square }\end{array}$ & F & Sig. \\
Between Groups & 5636,737 & 3 & 1878,912 & 2,773 &, $045^{*}$ \\
Within Grouops & 66395,616 & 98 & 677,506 & & \\
Total & 72032,353 & 101 & & & \\
\hline
\end{tabular}

Table 2 demonstrates that there is a significant difference between the retention performances of the groups 5 minutes after $(p<0.05)$. With the purpose of determining the groups between which there was a significant difference, a LSD test was conducted. The results of the test showed that Group 4 had better retention performance than Group $1(\mathrm{p}=0,014<0,05)$ and Group $3(\mathrm{p}=0,021<0,05)$; yet, there was no difference between Group 4 and Group 2.

\section{Findings on the Second Research Problem}

The second research problem is as follows: "How do different learning conditions (Study groups: Group 1: Study-Study-Test and Group 3: Study-Study-Study-Test, Test groups: Group 2: Study-Test-Test and Group 4: Study-Test-Test-Test) in learning the topic of Safe Internet Use affect the retention performance of learners 1 week after?" Table 3 presents the results of the analysis on the retention performances of the learners on the topic of Safe Internet Use 1 week after; Figure 4 presents the graphic showing the distribution of the retention performances of the learners according to the groups. 


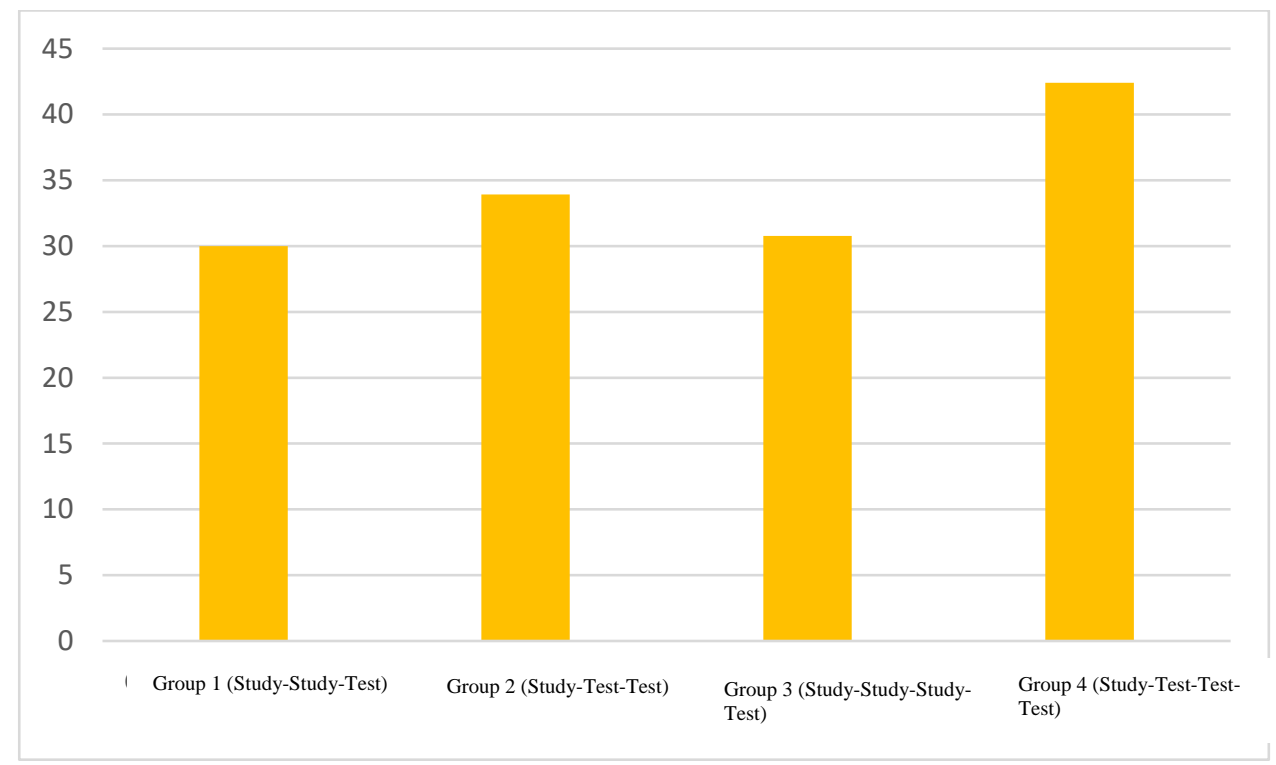

Figure 4. Distribution of Groups' 1 Week After Retention Performance

As explained in the graph in Figure 4, the group with the highest retention performance 1 week after was the group which took the most tests (Group $4(\mathrm{M}=42,4)$ ), which was followed by the group which took two tests (Group $2(M=33,929))$, the group which studied most (Group $3(\mathrm{M}=30,769)$ ), and the group which studied least (Group $1(\mathrm{M}=30)$ ). ANCOVA was performed in order to identify any significant difference between the retention performances of the groups.

Table 3. ANCOVA Results of Groups' 1 Week After Retention Performance

\begin{tabular}{lccccc}
\hline Source of Variance Sum of Squares & df & Mean Square & F & p \\
5 minutes after & 29229,744 & 1 & 29229,744 & 87,297 &, 000 \\
Group & 199,566 & 3 & 66,522 &, 199 &, $897 *$ \\
Error & 32478,729 & 97 & 334,832 & & \\
Total & 184200,000 & 102 & & & \\
\hline
\end{tabular}

Table 3 shows that there was no significant difference between the retention performances of the learners 1 week after when their retention performances 5 minutes after were taken into consideration ( $\mathrm{p}>0.05)$.

\section{Findings on the Third Research Problem}

The third research problem is as follows: "How does the retention performance of learners 5 minutes and 1 week after vary according to different learning conditions (Study groups: Group 1: Study-Study-Test and Group 3: Study-Study-Study-Test, Test groups: Group 2: Study-Test-Test and Group 4: Study-Test-Test-Test) in learning the topic of Safe Internet Use?". Figure 5 presents the graph demonstrating the distribution of the retention performances of the learners according to the groups; Table 4 provides the results of the analysis on the retention performances of the learners 5 minutes after and 1 week after. 


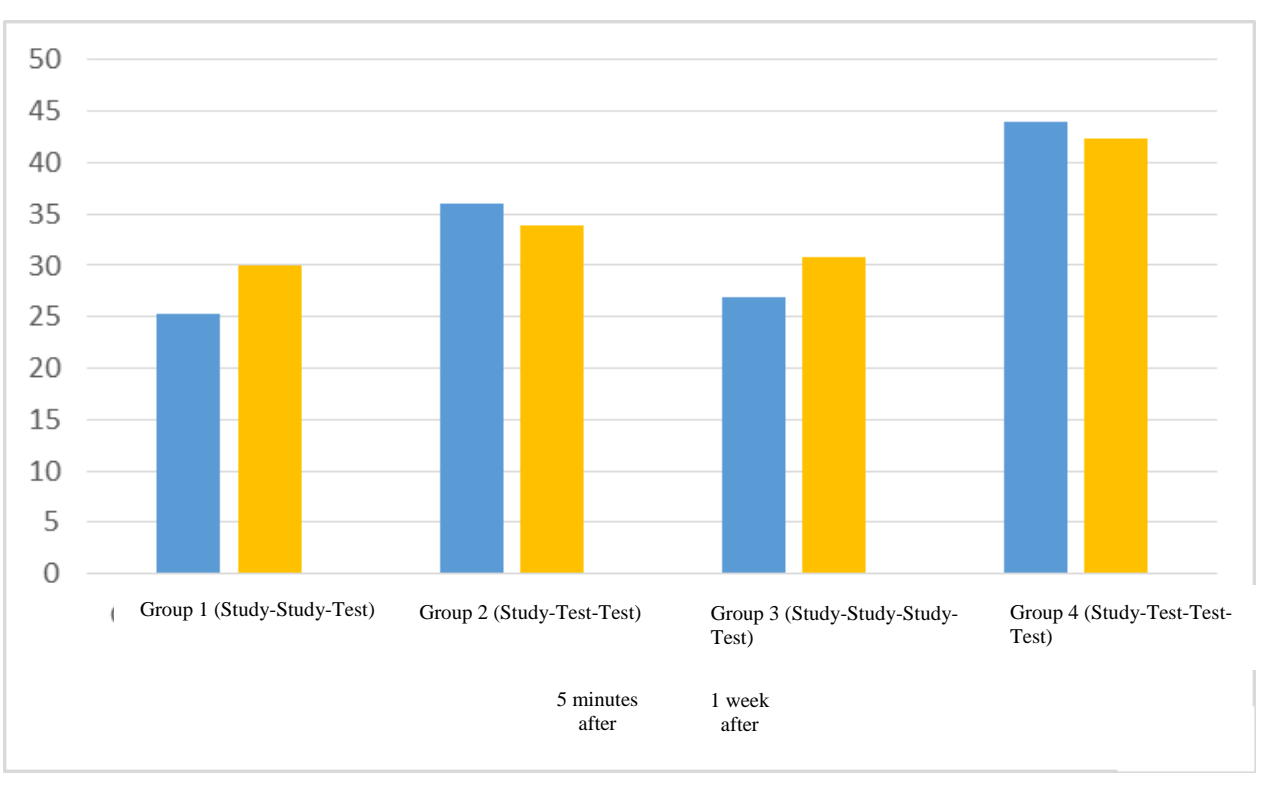

Figure 5. Change of Groups' Retention Performance from 5 Minutes to 1 Week

As illustrated in the graph in Figure 5, while the learners in Group 1 (Study-Study-Test) and Group 3 (StudyStudy-Study-Test) had lower retention performance 5 minutes after (Group $1(\mathrm{M}=25,217)$ and Group 3 (M= 26,923)), there was an increase in their retention performance 1 week after (Group $1(\mathrm{M}=30)$ and Group 3 $(\mathrm{M}=30,769))$. On the other side, whereas the learners in Group 2 (Study-Test-Test) and Group 4 (Study-Test-TestTest) had higher retention performance 5 minutes after (Group $2(\mathrm{M}=36,071)$ and Group $4(\mathrm{M}=44)$ ), there was a decline in their retention performance 1 week after (Group $2(M=33,929)$ and Group $4(M=42,4)$ ). A Paired Sample $\mathrm{t}$ test was performed to see whether such finding was statistically significant for each group or not.

Table 4. Paired Sample t test Results of Change of Groups' Retention Performance From 5 Minutes to 1 Week

\begin{tabular}{lccccc}
\hline & $\bar{X}$ & sd & $\mathbf{t}$ & $\mathbf{d f}$ & Sig. \\
Group 1 (Study-Study-Test) & $-4,783$ & 16,479 & $-1,392$ & 22 &, $178^{*}$ \\
Grup 2 (Study-Test-Test) & 2,143 & 19,693 &, 576 & 27 &, $570^{*}$ \\
Grup 3 (Study-Study-Study-Test) & $-3,846$ & 20,799 &,- 943 & 25 &, $355^{*}$ \\
Grup 4 (Study-Test-Test-Test) & 1,600 & 23,036 &, 347 & 24 &, $731^{*}$ \\
\hline
\end{tabular}

Table 4 indicates that there was no significant difference between the retention performances of the groups 5 minutes after and 1 week after $(\mathrm{p}>0.05)$.

\section{Findings on the Fourth Research Problem}

The fourth research problem is as follows: "What are the opinions of the learners regarding the learning process?" Regarding this research problem, the learners were asked to answer this question: "In your opinion, how did the studying method that you used affect your learning of the topic of Safe Internet Use? Please explain." After the analysis of the answers, the effect of the learning condition on motivation and participation as well as the effect of the learning condition on learning performance were presented under the relevant sections.

\section{Effect of Learning Condition on Motivation and Participation}

This section presents the analysis of the answers given by the learners about the learning condition. While a vast majority of the learners (Group $1=21$ people, Group 2=23 people, Group 3=22 people and Group $4=20$ people) reported that the learning condition positively affected motivation and course participation, few of them (Group $1=2$ people, Group $2=3$ people, Group $3=0$ person and Group $4=5$ people) stated that the learning 
condition did not affect motivation and course participation. Some learners did not express any opinion (Group 1 $=2$ people, Group $2=4$ people, Group $3=4$ people).

As mentioned above, a great majority of the learners in all groups ( 86 people) stated that the learning condition positively affected motivation and course participation. It can be said that the applied research design enabled the learners to experience a process in which they could be actively involved, which might have effect on the positive opinions among the learners. Below are some of the opinions of the learners who expressed such opinions:

Group 1 (Study-Study-Test): "This method was effective for me, increased my course participation. I am satisfied with this practice...", "It positively affected us since it was a good practice, fun..."

Group 2 (Study-Test-Test): "It was effective, further, it was very fun...", "It was more effective, since learning something by enjoying it is the best."

Group 3 (Study-Study-Study-Test): "It positively affected me. I wish such activities were performed all the time. It positively influenced me..." "It was a very useful practice for me. I want it to be always like that."

Group 4 (Study-Test-Test-Test): "Very effective. It was very helpful to me...", "In my opinion, this is a good method. It is very fun..."

\section{Effect of Learning Condition on Learning Performance}

This section presents the analysis of the answers given by the learners about the effect of the learning condition (testing or studying) on their learning performance. A great majority of the learners (Group $1=19$ people, Group $2=24$ people, Group $3=21$ people and Group $4=21$ people) expressed that the learning process had a positive effect on their learning. There were very few learners who stated that the learning process adversely influenced their learning (Group $1=1$ person, Group $2=2$ people, Group $3=0$ person and Group $4=4$ people). Some did not express any opinion (Group $1=3$ people, Group $2=2$ people, Group $3=5$ people). Below are some of the opinions of the learners:

Group 1 (Study-Study-Test): “...Learning became easier for me.”, “...provided more information to us. I learnt it very easily."

Group 2 (Study-Test-Test): “... Through this method, I learnt it better and it was much easier.”, “...Thanks to this activity, I understood and learnt it better.”

Group 3 (Study-Study-Study-Test): “...I learnt it easier in this way.”, “...I learnt it more effortlessly.”

Group 4 (Study-Test-Test-Test): “...I think that this activity was useful to me. I learnt better.", "In my opinion, this is a good method... I believe that I learnt it easier in this way."

On the other hand, it is remarkable that the learners in Group 4 with the learning condition of testing, who expressed that the learning process did not positively affect their motivation and participation, found repeated tests boring. Given the opinions of the learners in Group 4, it can be claimed that an increase in the number of tests may adversely affect the learners in a young age group. Below are some of the opinions of the learners who expressed such opinions:

"It was effective to some extent. It was boring to constantly answer questions. I feel that I learnt better, but it seemed to be more difficult... That is, I am a bit confused about it."

"It did not work for me. Since it was boring to solve the questions..."

\section{Discussion and Conclusion}

This study investigated the effect of different combinations (Study-Study-Test, Study-Test-Test, Study-StudyStudy-Test and Study-Test-Test-Test) of learning conditions (retesting or restudying) on the retention performance of secondary-school students in learning the topic of Safe Internet Use. It concluded that the group which took the most tests (Group 4) outperformed the study groups (Group 1 and Group 3) in terms of the retention performance 5 minutes after; nevertheless, there was no difference between Group 4 and the other test group, namely Group 2. Such finding seems to contradict with the findings of the study by Roediger \& Karpicke (2006b), who revealed 40 
that the group, which studied the most, outperformed the other group in terms of the retention performance 5 minutes after.

A statistically significant difference was not found when the groups' performance after 1 week and the change in performance from 5 minutes to 1 week were examined. Atabek Yiğit et al. (2014) and Demiraslan Çevik and Çoban (2016) determined that there was no difference between the test group and the restudying group in terms of long-term retention performance. However, many studies in the literature asserted that the groups with the learning condition of testing had better performance in terms of retention of information (eg Butler et al., 2007; Butler \& Roediger, 2007; McDaniel et al., 2007a; McDaniel et al., 2007b; Roediger \& Karpicke 2006b). The basic assumption of the testing effect is that testing learning information would enhance the recall of learnt information. Chan, Wilford \& Hughes (2012) note that this situation can also increase the recall of false information. In the scope of this study, no feedback was given to the learners regarding their wrong or incomplete answers. Given this situation, it is thought that this hypothesis, which is called misinformation effect, may be one of the reasons why testing effect can not be revealed.

It is notable that the studies in the field of psychology on the testing effect employed recognition and retention tests. Yet, there are a range of tests in use in educational environment. Indeed, Roediger \& Karpicke (2006b) analyzed the studies on these two tests, pointed out the difference between them, and reported that the applied type of test might play a role in the emergence of the testing effect. The researchers also emphasized that the effect of different types of tests on the emergence of the testing effect in educational environment has not sufficiently studied yet. Remarkably, the studies on the testing effect in the field of education utilized short-answer, multiplechoice, true/false questions and fill-in-the-blank questions. In the present study, unlike other studies, the test material asked the learners to analyze the presented case study and to recall the relevant item. It can be stated that such tests are relatively more difficult since they require learners to analyze the given situation and to pair it with the corresponding answer. This might be one of the reasons for failing to reveal the testing effect.

As mentioned earlier, there was no difference between the learners in the retest and study groups in terms of long-term retention performance. Further, the learners in both groups reported that the learning process positively affected their motivation and course participation and enabled them to learn the topic more easily. This finding may result from the fact that the applied research design provided the learners the opportunity to experience a learning process where they could be active. Another reason why the learners in the study group expressed such opinion might be that the learners preferred to prepare for an exam mostly by reading the material (Atebik Yiğit vd., 2014). Besides, contrary to the expectations, the group which took the most tests did not exhibit a better retention performance in the present study. The learners in this group, who expressed that the learning process was not effective and that they learnt the topic in a more difficult way, notably found repeated tests boring. For that reason, it can be argued that an increase in the number of tests might negatively affect the learners in a young age group. Yet, similar studies are necessary to prove it.

In conclusion, this study failed to put forward statistically significant findings on long-term retention performance regarding the testing effect. The potential reasons are explained above. It is noteworthy that the studies on the testing effect, particularly among the learners in a young age group, are limited and the studies comparing different combinations of learning conditions (retesting or restudying) are few in number. It is suggested that further studies may focus on such areas; the present study can be replicated with a larger group of learners and the studies with participants in a young age group might perform different tests and concentrate on the testing effect as well. 


\title{
Sınama Etkisinde Farklı Öğrenme Koşullarının İncelenmesi: Güvenli İnternet Kullanımı Konusu Örneği
}

\author{
Giriş
}

Eğitim ile ilgili gerçekleştirilen faaliyetlerin temel amacı belirlenen hedeflere ulaşabilmek ve belirli işlevleri yerine getirmektir (Şişman, 2011). Bu açıdan bakıldığında ölçme ve değerlendirme etkinliklerinin belirlenen hedeflere ne derecede ulaşılabildiğini saptamada ve eğitim süreci ile ilgili bilgi sağlamada önemli bir role sahip olduğu söylenebilir. Eğitimde değerlendirme işlemini gerçekleştirmek için sözlü sınavlar, yazılı sınavlar, kısa cevaplı testler, doğru yanlış testleri ve çoktan seçmeli testler gibi birçok ölçme aracı kullanılmaktadır. Bellek ile ilgili yürütülen araştırmalarda testlerin değerlendirme için kullanımının yanı sıra öğrenilen bilginin hatırlanmasında da olumlu bir katkısı olduğu belirtilmektedir (Darley \& Murdock, 1971; McDaniel, Kowitz, \& Dunay, 1989; Whitten \& Bjork, 1977). Sınama etkisi olarak adlandırılan bu durum, bir materyale defalarca çalışıp sonrasında sınanmaktansa, bir kere çalışıp birçok kez sınanmanın materyaldeki bilgilerin daha iyi hatırlanmasına yardımcı olduğu sayıltısına dayanmaktadır.

Sınama etkisinin daha iyi hatıllama performansı sağlaması ile ilgili Terry (2011) üç farklı açıklama belirtmektedir: (1) Sınama, çalışmanın bir başka şeklidir ve materyalin pasif olarak ikinci kez tekrarından daha ilginç bir yeniden çalışma olanağı sunmaktadır, (2) Sınav sorularını cevaplamak materyali okuyarak tekrar çalışmaktan daha fazla bilişsel çaba gerektirir, (3) Aktarıma uygun işleme yaklaşımına göre, geri getirme sırasında yürütülen işlemler kodlama sırasındaki işlemlere ne kadar benzerse, geri getirme o kadar başarılı olur. $\mathrm{Bu}$ bağlamda sınav olarak çalışma, bilginin bellekten geri getirilmesi sürecine benzer olduğu için daha iyi hatırlama performansı sergilenmesine imkân sağlamaktadır. Roediger, Putnam ve Smith de (2011, s. 4) sinama etkisinin eğitim ortamında bireysel bir çalışma stratejisi veya sınıf taktiği olarak uygulandığı takdirde sağlayacağı 10 faydaya dikkati çekmektedirler:

1. Sınanmak, bellekten bilgilerin çağırılmasına yardımcı olur,

2. Sınanmak, bilgideki boşlukları tanımlar,

3. Sınanmak, öğrenenlerin bir sonraki öğrenme bölümünden daha fazla bilgi almasını sağlar,

4. Sinanmak, bilginin daha iyi düzenlenmesini sağlar,

5. Sınanmak, bilginin yeni bağlamlara aktarılmasını geliştirir,

6. Sınanmak, test edilmemiş bilgilerin hatırlanmasını kolaylaştırabilir,

7. Sınanmak, üst bilişsel izlemeyi geliştirir,

8. Sınanmak, yeni bir materyali öğrenirken önceki materyalin etkileşimini önler,

9. Sınanmak, öğretmenlere geribildirim sağlar,

10. Sık yapılan testler öğrencileri çalışmaya teşvik eder.

Eğitim sürecinde gerçekleştirilen öğrenme faaliyetlerinin daha kalıcı ve nitelikli olması amaçlanmaktadır. Deneysel psikoloji alanında sınama etkisinin, bu amacı gerçekleştirme potansiyeli olabileceğine dair elde edilen bulgulardan sonra, eğitim alanında da birçok araştırmacı tarafından yürütülen çalışmalarla sınama etkisi araştırılmıştır. Bu çalışmalarda sınama etkisinin ortaya çıkmasında dönütün, farklı test türlerinin ve farklı çalışma koşullarının etkisi üzerinde durulmuştur. Örneğin Agarwal, Karpicke, Kang, Roedige ve McDermott (2008) öğrencilerin sınav olurken kitapları ve notları taradıkları açı kitap testleri ve kitap ve notları tarayamadıkları kapalı kitap testlerinde dönütün sağlandığı ve sağlanmadığı koşullarda sınama etkisini araştırmak üzere üniversite öğrencileri ile bir çalışma gerçekleştirmişlerdir. Öğrenciler öncelikle düz metinlere çalışmış, sonrasında ya konuya tekrar çalışmış ya da dönüt sağlandığı ve sağlanmadığı koşullarda açık veya kapalı kitap testlerini olmuşlardır. Araş̧ırma sonucunda dönüt sağlanan her iki tekrar sınama koşulunun uzun süreli hatırlamada tekrar çalışma ve dönütün sağlanmadığı koşullardaki öğrenenlere göre daha iyi olduğu bulunmuştur. Ayrıca açık kitap tekrar sınama koşulundaki öğrenenlerin kapalı kitap tekrar sınama koşulundaki öğrenenlere göre kısa süreli hatırlamada daha iyi performans sergiledikleri belirlenmiştir. Ancak uzun süreli hatırlamada bu iki grup arasında herhangi bir farklılık bulunamamıştır.

Butler ve Roediger ise (2007) testlerin uzun süreli hatırlamayı nasıl etkilediğini araştırmak üzere üniversite öğrencileri ile dersin özetine çalışan, çoktan seçmeli test olan veya kısa cevaplı test olan grupları karşılaştırdığı bir çalışma gerçekleştirmişlerdir. Araştırmada öğrenme koşulu sınanmak olan grupların cevaplarının yarısına doğru cevap dönüt olarak sağlanmıştır. Araştırma sonucunda uzun süreli hatırlamada kısa cevaplı testlerin uygulandığı grubun diğerlerine göre daha iyi performans sergilediği bulunmuştur. Tekrar çalışan ve çoktan seçmeli test olan 
grupların herhangi bir müdahale uygulanmayan gruba göre uzun süreli hatırlamada daha iyi performans sergiledikleri belirlenmiştir. Agarwal ve diğerlerinin (2008) sonuçlarının aksine bu çalışmada dönüt sağlanmasının grupların hatırlama performansına herhangi bir etkisi olmadığı bulunmuştur.

Bir başka çalışmada, Butler, Karpicke ve Roediger (2007) dönüt türünün ve zamanlamasının çoktan seçmeli bir testten öğrenmeyi nasıl etkilediğini araştırmak üzere bir çalışma gerçekleştirmişlerdir. Araştırmada öğrenciler öncelikle uzunluğu 280-300 kelime arasında değişen metinler okumuşlardır. Sonrasında öğrencilere metinlerdeki bilgilerle ilgili 6 seçenekten oluşan çoktan seçmeli test uygulanmıştır. Öğrenciler ya doğru cevabın verildiği ya da doğru cevaba ulaşana kadar yanıtlamaya devam ettikleri iki farklı dönüt türü almışlardır. Bu dönütler çoktan seçmeli maddelerin bir kısmı için hemen sağlanırken, diğerleri için gecikmeli olarak sağlanmıştır. Son testte uygulanan dönüt türü açısından herhangi bir farklılık olmadığı ancak gecikmeli dönüt alan grubun anında dönüt alanlara göre daha iyi performans sergilediği bulunmuştur.

Larsen, Butler ve Roediger (2009) tıp öğrencilerinin kesintisiz epilepsi veya çizgili kas hastalığı konularını öğrenmesinde test etkisini araştırmak üzere bir çalışma gerçekleştirmişlerdir. Araştırmada öğrenciler öncelikle bu konuların anlatıldığı bir eğitim almışlar, sonrasında iki gruba ayrılmışlardır. Gruplardan biri kesintisiz epilepsiye tekrar çalışma durumunu ve çizgili kas hastalığı ile ilgili tekrar sınanma durumunu gerçekleştirirken, diğer grup çizgili kas hastalığına tekrar çalışma ve kesintisiz epilepsi ile ilgili tekrar sınanma durumunu gerçekleştirmiştir. Araştırma sürecinde sınama grubundaki öğrenenlere dönüt sağlanmıştır. Öğrencilere 6 ay sonra uygulanan testte öğrenme koşulu tekrar sınanmak olan grubun daha yüksek performans sergilediği bulunmuştur. Carpenter, Pashler \& Cepeda da (2009) benzer bir şekilde öğrenilen bilginin uzun süre (16 hafta) sonra hatırlanmasında tekrar sinanma grubunun daha iyi performans sergilediğini bulmuşlardır.

McDermott ve diğerleri (2014) farklı test türlerinin ortaokul ve lise öğrencilerinin öğrendikleri bilgiyi hatırlamalarına etkisini araştırmak üzere bir çalışma gerçekleştirmişlerdir. Araştırma sürecinde bir grup çoktan seçmeli ve kısa cevaplı testlerden oluşan quizler olmuş ve bu quizlerle ilgili dönüt almıştır. Diğer grup ise öğrenilen konuya tekrar çalışmış̧ır. Araştırma sonunda öğrenme koşulu tekrar sınanma olan grubun tekrar çalışma grubuna göre öğrenilen bilgiyi daha iyi hatırladığı bulunmuştur. Ayrıca öğrenilen bilginin hatırlanmasında çoktan seçmeli testlerin kısa cevaplı testler kadar etkili olduğu bulunmuş̧ur. McDaniel, Anderson, Derbish \& Morrisette (2007a) ve McDaniel, Roediger \& McDermott (2007b) ise bu çalışmanın aksine öğrenilen bilginin hatırlanmasında kısa cevaplı testlerin çoktan seçmeli testlere göre daha etkili olduğunu bulmuşlardır. Atabek Yiğit ve Balkan Kıyıcı da (2016 ) sınma etkisinde farklı test türlerini (doğru yanlış, çoktan seçmeli ve boşluk doldurma) araştırdıkları çalışmalarında doğru yanlış testlerinin daha etkili olduğunu, bunu sırasıyla boşluk doldurma ve çoktan seçmeli testlerin takip ettiğini bulmuşlardır.

Atabek Yigit, Balkan Kiyici ve Çetinkaya (2014) Fen Bilgisi öğretmen adaylarının (n=98) "Bileşiklerin İsimlendirilmesi” konusunu öğrenmelerinde farklı destek etkinlikleri ile sağlanan (çoktan seçmeli testler, eşleştirme testleri ve çalışma yaprakları) öğrenme koşulunun (sınama veya tekrar çalışma) dönüt ile desteklenmesi veya son testin farklı zamanlarda (1 gün sonra: Kısa süreli ve 1 hafta sonra: Uzun süreli hatırlama) uygulanmasının sınama etkisinin ortaya çıkmasındaki rolünü araştırdıkları çalışmalarında, öğrenenlere 100 kısa cevaplı sorudan oluşan bir ön test uygulamış sonrasında öğrenenleri 6 deney (G1, G2, G3, G4, G5 ve G6), 1 kontrol grubuna ayırmışlardır. Öğrenme koşulu sınanmak olan dört deney grubundan G1 ve G3'e uygulamadan sonra dönüt verilmemiş, son test G1'e 1 gün sonra, G3'e 1 hafta sonra uygulanmıştır. G2 ve G4 gruplarına ise dönüt verilmiş, son test G2 grubuna 1 gün sonra, G4 grubuna 1 hafta sonra uygulanmıştır. Öğrenme koşulu tekrar çalışmak olan diğer iki deney grubundan G5'e son test 1 gün sonra uygulanırken, G6'ya 1 hafta sonra uygulanmıştır. Kontrol grubuna araştırma süresince herhangi bir müdahalede bulunulmamıştır. Araştırma sonucunda farklı destek etkinlikleri (çoktan seçmeli testler, eşleştirme testleri ve çalışma yaprakları) açısından deney gruplarının son test performanslarındaki artış istatistiksel olarak anlamlı bulunmuştur. Buradan yola çıkarak da uygulama tipinin (sınanma veya tekrar çalışma) ne olduğu önemli olmaksızın öğrenilen bilginin hatırlanmasında destek etkinliklerinin (çoktan seçmeli testler, eşleştirme testleri ve çalışma yaprakları) olumlu bir katkısı olduğu yorumu yapılmıştır. Ancak test türü, dönüt veya son testin farklı zamanlarda (1 gün sonra: Kısa süreli ve 1 hafta sonra: Uzun süreli hatıllama) uygulanması açısından gruplar arası karşılaştırmalar istatistiksel olarak anlamlı bulunmamıştır

Roediger ve Karpicke (2006b) sınama etkisinde farklı öğrenme koşullarının 5 dakika, 2 gün ve 1 hafta sonraki hatırlama performanslarını araştırmak üzere üniversite öğrencileri ile iki deney gerçekleştirmiştir. Birinci deneyde öğrenciler Çalış-Çalış ve Çalış-Sına olmak üzere iki gruba ayrılmış ve öğrenme koşuluna uygun olarak çalışmıştır. 
Sonrasında Gruplara 5 dakika, 2 gün ve 1 hafta aralıklarla test uygulanmıştır. Analizler sonucunda 5 dakika sonraki hatırlama performansında çalışma grubunun daha iyi performans sergilemiştir. Ancak iki gün ve 1 hafta sonraki testlerde sınama grubu çalışma grubundan daha iyi performans sergilemiştir. İkinci deneyde öğrenciler ÇalışÇalış-Çalış-Çalış, Çalış-Çalış-Çalış-Sına ve Çalış-Sına-Sına-Sına olmak üzere üç gruba ayrılmış ve öğrenme koşuluna uygun olarak çalışmışlardır. Sonrasındaysa gruplara 5 dakika ve 1 hafta aralıklarla test uygulanmıştır. Analizler sonucunda 5 dakika sonraki hatırlama performansında Çalış-Çalış-Çalış-Çalış grubunun daha iyi performans sergilediği, bunu sırasıyla Çalış-Çalış-Çalış-Sına ve Çalış-Sına-Sına-Sına gruplarının takip ettiği belirlenmiştir. Bir hafta sonraki performanslarda ise Çalış-Sına-Sına-Sına grubunun daha iyi performans sergilediği bunu sırasıyla Çalış-Çalış-Çalış-Sına ve Çalış-Çalış-Çalış-Çalış gruplarının takip ettiği bulunmuştur.

Dobson ve Perez (2016) sınama etkisinde aralıklı ve tek seferde öğrenmenin etkilerini araştırmak üzere bir çalışma gerçekleştirmiştir. Araştırma sürecinde öğrenenler tekrar çalışmanın 3 farklı günde yapıldığ 1 (Çalış-ÇalışÇalış-Çalış), tekrar çalışma ve testin üç farklı günde yapıldığı (Çalış-Sına-Çalış-Sına), iki farklı günde tekrar çalışmanın yapıldı ̆̆ 1 (Çalış- Çalış- Çalış- Çalış- Çalış-Çalış), iki farklı günde tekrar çalışma ve sınamanın yapıldığ (Çalış-Sına-Çalış-Sına-Çalış-Sına) ve son olarak tek seferde tekrar çalışma ve sınamanın yapıldığı (Çalış-SınaÇalış-Sına-Çalış-Sına) olmak üzere 5 gruba ayrılmıştır. Öğrenmeden 1 hafta sonra uygulanan test sonuçlarına göre tekrar çalışmanın 3 farklı günde yapıldığı (Çalış-Çalış-Çalış-Çalış) gruptaki öğrencilerin daha iyi performans sergilediği bunu sırasıyla tekrar çalışma ve testin üç farklı günde yapıldığı (Çalış-Sına-Çalış-Sına), iki farklı günde tekrar çalışmanın yapıldığı (Çalış- Çalış- Çalış- Çalış- Çalış-Çalış), iki farklı günde tekrar çalışma ve sınamanın yapıldığı (Çalış-Sına-Çalış-Sına-Çalış-Sına) ve son olarak tek seferde tekrar çalışma ve sınamanın yapıldığı (ÇalışSına-Çalış-Sına-Çalış-Sına) grupların takip ettiği belirlenmiştir.

Demiraslan Çevik ve Çoban'ın (2016) Bilişim Teknolojileri öğretmen adaylarının (n=33) “Dijital Mülkiyet Ve Siber Etik" konularını öğrenmelerine farklı öğrenme koşullarının (tekrar çalışma veya sınanma) etkisini araştırdıkları çalışmalarında, öğrenenleri Grup 1 (Çalış-Çalış-Sına) ve Grup 2 (Çalış-Sına-Sına) olmak üzere 2 gruba ayrmış ve 2 haftalık bir uygulama süreci gerçekleştirmişlerdir. İlk hafta Grup 1'deki öğrenenler 10 dakika dijital mülkiyet konusuna çalışmış, sonrasında 2 dakikalık çarpma işlemlerinden oluşan oyalama görevi verilmiş, devamında tekrar 10 dakika çalışmış, 5 dakika çarpma işlemlerinden oluşan oyalama görevi verilmiş ve 10 dakika test uygulanmıştır. Sonrasında Grup 1'de yer alan öğrenenler aynı sırayla siber etik konusuna çalışmışlardır. Grup 2'de yer alan öğrenenler ise 10 dakika dijital mülkiyet konusuna çalışmış, sonrasında 2 dakikalık çarpma işlemlerinden oluşan oyalama görevi verilmiş, devamında 10 dakika test uygulanmış, 5 dakikalık çarpma işlemlerinden oluşan oyalama görevi verilmiş ve 10 dakika test uygulanmıştır. Sonrasında Grup 2'de yer alan öğrenenler aynı sırayla siber etik konusuna çalışmışlardır. İkinci hafta ise her iki gruptaki öğrenenlere 10 dakika son test tekrar uygulanmıştır. Araştırma sonucunda öğrenme koşulu tekrar çalışma olan öğrenenlerin hatırlama düzeyleri 1.test (5 dakika sonra) sonrası daha yüksek iken, öğrenme koşulu sınanmak olan öğretmen adaylarının kalıcılık testinde (1 hafta sonra) daha yüksek hatırlama düzeyine sahip oldukları görülmüş ancak bu fark istatistiksel olarak anlamlı bulunmamıştır.

Alan yazında yürütülen çalışmalar incelendiğinde büyük bir kısmının üniversite ya da lise düzeyi katılımcılarla gerçekleştirildiği (Örneğin, Agarwal vd., 2008; Atabek Yigit vd., 2014; Atabek Yiğit \& Balkan Kıyıc1, 2016; Demiraslan Çevik \& Çoban, 2016; McDaniel vd., 2007a; Roediger \& Karpicke, 2006b; Butler \& Roediger, 2007) görülmektedir. Ayrıca McDaniel ve diğerleri (2007b) daha küçük yaş gruplarındaki öğrencilerle gerçekleştirilen çalışmaların yapılmasına ihtiyaç olduğunu söylemektedirler. Öte yandan ülkemizde sınama etkisinin araştırıldığı çalışmaların oldukça az olduğu dikkati çekmektedir (Örneğin, Atabek Yigit vd., 2014; Atabek Yiğit \& Balkan Kıyıc1, 2016; Demiraslan Çevik \& Çoban, 2016 ).

Sınama etkisinin araştırıldığı çalışmalarda genellikle katılımcılar önce materyale çalışmakta sonrasında ya tekrar sınanmakta ya da tekrar çalışmaktadır (Terry, 2011). İlgili alan yazında daha fazla sınav olmanın uzun süreli hatırlamaya olumlu bir etkisi olduğu söylenmektedir (Roediger \& Karpicke, 2006b). Bu görüşe paralel bir şekilde Demiraslan Çevik \& Çoban da (2016) öğrenme koşulu tekrar sınanmak olan grupların test sayılarının artırılmasının daha olumlu sonuçlar doğurabileceğini söylemektedirler. Ancak yapılan çalışmalar incelendiğinde öğrenme koşulunun (sınanmak veya tekrar çalışmak) farklı kombinasyonlarının (Çalış-Çalış-Son Test, Çalış-Sına-Son Test, Çalış-Çalış-Çalış-Son Test ve Çalış-Sına-Sına-Son Test) öğrenilen bilginin hatırlamasına etkisiyle ilgili yürütülen çalışmaların az olduğu göze çarpmaktadır (örneğin, Roediger \& Karpicke, 2006b ). Bu çalışma kapsamında literatürdeki boşluklar göz önünde bulundurularak ortaokul öğrencileri ile gerçekleştirilecek olan bir çalışma ile öğrenme koşulunun farklı kombinasyonlarının öğrenilen bilginin hatırlanmasına etkisinin araştırılması 
amaçlanmaktadır. Günümüzde öğrenenlere kazandırılması gereken önemli becerilerden birinin de Güvenli İnternet Kullanımı konusu olduğu düşünülmektedir. Bu çalışma kapsamında bu konunun öğrenilmesinde sınama etkisinin incelenmesi planlanmaktadır. Bir sonraki bölümde buna dair alan yazın sunulacaktır.

\section{Güvenli İnternet Kullanımı}

1920’lerin başlarında radyonun icadı ile başlayıp televizyon, bilgisayarlar, tablet ve akıllı telefonların icadı ile devam eden teknolojideki -özellikle Bilgi ve İletişim Teknolojilerindeki (BİT)- gelişmeler sayesinde internetin giderek hayatımızın neredeyse vazgeçilmez bir parçası haline geldiği söylenebilir (Heesen, 2012). Bunun bir sonucu olarak da BİT'in diğer birçok alanda olduğu gibi eğitim alanında da yaygın bir şekilde kullanımı artmaktadır. Hatta birçok ülkenin bu doğrultuda teknoloji politikalarını yapılandırdığı ve BİT’in eğitim ortamlarında etkin bir şekilde kullanılmasını artırmaya yönelik çeşitli projeler (örneğin ülkemizde FATİH projesi) geliştirdiği görülmektedir.

Tüm bu gelişmeler göz önünde bulundurulduğunda, ülkemizde 16-74 yaş arası bireylerin internet kullanım oranının 2010 yılında \%41.6 iken 2016 yılında bu oranın \%61.2'ye yükseldiği (TÜİK,2010; TÜİK,2016) ve 0615 yaş arası çocukların internet kullanmaya başlama yaş ortalamasının 9 olduğu dikkati çekmektedir (TÜİK, 2013). Ancak internet kullanımındaki bu artışın interneti tıpkı gerçek dünyada olduğu gibi birçok farklı bireyin ve risklerin bulunduğu sanal bir dünya haline getirdiği, bu durumunda özellikle internet kullanımı sırasında karşılaşabileceği tehlikeler ile ilgili bilgisi olmayan çocuklar üzerinde bir risk faktörü oluşturduğu belirtilmektedir (Karakuş, Çağıltay, Kaşıkc1, Kurşun \& Ogan, 2014).

Alan yazında yürütülen çalışmalarda da internetin bilinçsiz ve aşırı kullanımının bireylerin yaşam doyumunu düşürdüğü (Köse, 2016), depresyon eğilimini (Morrison \& Gore, 2010) ve bireylerde yalnızlığı (Meral \& Bahar, 2016) artırdığı görülmektedir. Ayrıca özellikle küçük yaş grubu çocukların internette kişisel bilgilerinin istendiği ve kendisiyle sohbet etmek isteyen yabancılarla karşılaştığı riskli durumlara maruz kaldığı belirtilmektedir (Ersoy \& Yılmaz, 2015). Bu bağlamda birçok araştırmacı çocukların güvenli internet kullanımı ile ilgili bilinçlendirilmesi ve buna yönelik eğitim almalarının önemine dikkati çekmektedir (Ersoy \& Yılmaz, 2015; Takemura \& Umino, 2009; Tekin \& Polat, 2014). Aslan \& Karakuş Yılmaz (2017) ülkemizde güvenli internet kullanımına yönelik gerçekleştirilen uygulamaları inceledikleri çalışmalarında, ülkemizdeki çalışmaların bilinçlendirme seminerleri, etkinlikler, farkındalık ve tanıtım kampanyaları, basılı ve görsel materyaller, ihbar hattı, teknik ve yasal önlemler şeklinde gerçekleştirildiğini belirtmektedir. Konunun önemi göz önünde bulundurulduğunda, ülkemizde güvenli internet kullanımının öğrenilmesinde farklı öğrenme yöntemlerinin etkisinin araştırıldığı çalışmaların oldukça az olduğu dikkati çekmektedir (örneğin, Korkmaz \& Esen, 2016). Ayrıca ilgili alan yazında bu konunun öğrenilmesinde sınama etkisinin rolünün araştırıldığı bir çalışmaya rastlanmamıştır.

$\mathrm{Bu}$ nedenle bu çalışma kapsamında ortaokul öğrencilerinin Güvenli İnternet Kullanımı konusunu öğrenmelerinde öğrenme koşulunun (sınanma veya tekrar çalışma) farklı kombinasyonlarının (Çalış-Çalış-Sına, Çalış-Sına-Sına, Çalış-Çalış-Çalış-Sına ve Çalış-Sına-Sına-Sına) öğrenenlerin hatırlama performansları üzerine etkisi araştırılarak literatürde belirtilen boşlukların doldurulmasına katkı sağlanması amaçlanmaktadır. Çalışmanın amacına yönelik aşağıdaki araştırma soruları yanıtlanmaya çalışılacaktır:

1. Öğrenenlerin Güvenli İnternet Kullanımı konusunu öğrenmesinde farklı öğrenme koşullarının (Çalışma grupları: Grup 1: Çalış-Çalış-Sına ve Grup 3: Çalış-Çalış-Çalış-Sına, Sınama grupları: Grup 2: Çalış-SınaSına ve Grup 4: Çalış-Sına-Sına-Sına) öğrenenlerin $5 \mathrm{dk}$ sonraki hatırlama performanslarına etkisi nedir?

2. Öğrenenlerin Güvenli İnternet Kullanımı konusunu öğrenmesinde farklı öğrenme koşullarının öğrenenlerin 1 hafta sonraki hatırlama performanslarına etkisi nedir?

3. Öğrenenlerin Güvenli İnternet Kullanımı konusunu öğrenmesinde farklı öğrenme koşullarına göre 5 dk ve 1 hafta sonraki hatırlama performansları nasıl değişmektedir?

4. Öğrenenlerin gerçekleştirilen öğrenme sürecine ilişkin görüşleri nelerdir? 


\section{Yöntem}

\section{Araştırma Modeli}

Araştırmada öğrenenlerin Güvenli İnternet Kullanımı konusunu öğrenmelerinde öğrenme koşulunun (sınanma veya tekrar çalışma) farklı kombinasyonlarının (Çalış-Çalış-Sına, Çalış-Sına-Sına, Çalış-Çalış-Çalış-Sına ve Çalış-Sına-Sına-Sına) öğrenenlerin hatırlama performansları üzerine etkisini araştırmak üzere hem nicel hem de nitel yöntemlerin bir arada kullanıldığı karma araştırma yönteminden faydalanılmıştır. Araştırma sürecinde yararlanılan karma araştırma deseni açıklayıcı desendir. Bu desende önce nicel veriler toplanmakta sonrasında bu verileri desteklemek amacı nitel veriler toplanmaktadır (Büyüköztürk, Kılıç Çakmak, Akgün, Karadeniz \& Demirel, 2013; Fraenkel \& Wallen, 2003). Araştırmanın nicel boyutunda deneysel desenlerden yarı deneysel desen kullanılmıştır. Yarı deneysel desende araştırmanın katılımcılarının seçiminde seçkisizlik söz konusu değilken katılımcıların atanmasında seçkisizlik söz konusudur (Büyüköztürk vd., 2013). Araştırmanın nitel boyutundaysa içerik analizi yöntemi kullanılmıştır. İçerik analizi belirli kurallara dayalı kodlamalarla bir metnin bazı sözcüklerinin daha küçük içerik kategorileri ile özetlendiği sistematik ve yinlenebilir bir tekniktir (Büyüköztürk vd., 2013, ss.240).

\section{Çalışma Grubu}

Çalışma grubunu 2016-2017 eğitim öğretim döneminde Hatay’da bir ilköğretim okulunda öğrenim görmekte olan 102 (57 kız çocuğu, 45 erkek çocuğu) 6. Sınıf öğrencisi oluşturmaktadır. Ders öğretmeni ile yapılan görüşmeler neticesinde öğrenenlerin dersi ilk defa aldıkları belirlenmiş ve Güvenli İnternet Kullanımı konusu ile ilgili herhangi bir ön bilgilerinin olmadığı varsayılmıştır. Araştırma grupları rast gele olarak atanmıştır. Buna göre Grup 1 (Çalış-Çalış-Sına) ve Grup 3 (Çalış-Çalış-Çalış-Sına) tekrar çalışma ve Grup 2 (Çalış-Sına-Sına) ve Grup 4 (Çalış-Sına-Sına-Sına) sınama gruplarıdır. Grup1 'de 23, Grup2'de 28, Grup3'de 26 ve Grup4'de 25 kişi yer almiştır.

\section{Veri Toplama Araçları}

Araştırma sürecinde öğrenenlerin Güvenli İnternet Kullanımı konusuna çalışmaları için araştırmacılar tarafından kitapçık şeklinde bir çalışma materyali hazırlanmıştır. Bu materyalin hazırlanmasında Bilişim Teknolojileri (BT) öğretmenlerinin görüşlerinden ve Bilişim Teknolojileri ve Yazılım dersi kitabından yararlanılmıştır. Ayrıca materyalin tasarımında öğrenenlerin dikkatini çekecek görsel uyarıcılardan yararlanılmıştır. Materyal geliştirilirken içeriğin düzenlenmesi ve görsel uyarıcıların seçilmesi konusunda iki BT öğretmeninin fikirleri alınmıştır. Geliştirilen materyal ilk başta öğrenenlerin interneti kullanırken sıklıkla karşılaşabilecekleri tehlikeli durumlarda ne yapmaları ve nelere dikkat etmeleri gerektiği konularına ilişkin 10 madde ve bunların açıklamasından oluşmaktaydı. Çalışma kitapçığında yer alan bu maddeler ile ilgili olarak da örnek olay şeklinde tasarlanmış 10 sorudan oluşan, yüzeysel özellikleri farklı, yapısal özellikleri aynı olan testler (Test 1, Test 2 ve Test 3) geliştirilmiştir (Bakınız Ek 1, Ek 2, Ek 3). Araştırma için hazırlanan materyallerin değerlendirilmesi ve uygulama ile ilgili olası hataların belirlenebilmesi için aynı yaş grubunda 20 kişilik bir öğrenen grubu ile bir ön çalışma yapılmıştır. Yapılan çalışma sonucunda çalışma kitapçığındaki ve sınav materyallerindeki biçimsel hatalar ve ifade bozuklukları giderilmiştir. Ayrıca öğrenenlerin çalışmaları beklenen maddeler ders süreci ve uygulama göz önünde bulundurulduğunda fazla uzun geldiği için 10'dan 5'e indirilmiştir. Aynı şekilde geliştirilen test materyallerindeki soruların sayısı da 10'dan 5'e indirilmiştir. Öğrenenlerin çalışacağı 5 maddenin seçiminde BT öğretmenleri ile görüşülmüş ve alınan dönütler doğrultusunda öğrenenlerin günlük hayatta sıklıkla karşılaştıkları maddeler seçilmiştir. Uygulamadaki süreler ders saati göz önünde bulundurularak çalışma kitapçığı için 10 dakika, oyalama görevleri (Oyalama 1 ve Oyalama 2) için 2 dakika ve testler (Test 1, Test 2 ve Test 3 ) için 10 dakika olarak belirlenmiştir.

Geliştirilen testlerden Test 1 ve Test 2 çalışma materyali olarak, Test 3 ise öğrendikten kısa süre sonraki (5 dakika) ve uzun süre sonraki (1 hafta sonraki) hatırlama performanslarını karşılaştırmak içi kullanılmıştır. Uygulamada hatırlama performansını karşılaştırmak üzere belirlenen sürelerde alan yazında sınama etkisi ile ilgili yürütülen araştırmaların desenleri temel alınmıştır. Hazırlanan her üç testte de öğrenenlerin verilen örnek olayı incelemeleri ve onunla ilgili maddeyi hatırlamaları beklenmiştir. Öğrenenlerin çalıştıkları materyaller arasında oluşabilecek hatırlama etkisinin kaldırılmasına yönelik üç farklı oyalama görevi (Oyalama 1, Oyalama 2 ve Oyalama 3) geliştirilmiştir (Bakınız Ek 4, Ek 5, Ek 6). Çalışma ve sınama koşullarında kullanılan materyallerin içeriği sözel olduğu için oyalama aşamasında dört işlemden oluşan sayısal görevler kullanılmıştır. 


\section{Verilerin Toplanması}

Uygulama toplam iki hafta sürecek şekilde tasarlanmıştır. Uygulama sürecinin başında öğrenenlere süreç ile ilgili bilgi sağlanmıştır. Birinci hafta gruplar öğrenme koşullarına (sınanma veya tekrar çalışma) uygun materyalleri ve testleri almışlardır. Uygulamada ilk hafta gruplar için izlenen yol şu şekildedir: (1) Grup 1 (ÇalışÇalış-Sına) 10 dakika çalışma kitapçığında Güvenli İnternet Kullanımı konusuna çalışmış, sonrasında 2 dakikalık Oyalama 1 görevi verilmiş, devamında tekrar 10 dakika çalışmış, 5 dakikalık Oyalama 3 görevi verilmiş ve 10 dakika Test 3 uygulanmıştır, (2) Grup 2 (Çalış-Sına-Sına) 10 dakika çalışma kitapçığında Güvenli İnternet Kullanımı konusuna çalışmış, sonrasında 2 dakikalık Oyalama 1 görevi verilmiş, devamında 10 dakika Test 1 uygulanmış, 5 dakikalık Oyalama 3 görevi verilmiş ve 10 dakika Test 3 uygulanmıştır, (3) Grup 3 (Çalış-ÇalışÇalış-Sına) 10 dakika çalışma kitapçı̆̆ında Güvenli İnternet Kullanımı konusuna çalışmış, sonrasında 2 dakikalık Oyalama 1 görevi verilmiş, devamında tekrar 10 dakika çalışmış, 2 dakikalık Oyalama 2 görevi verilmiş, 10 dakika tekrar çalışmış, 5 dakikalık Oyalama 3 görevi verilmiş ve 10 dakika Test 3 uygulanmıştır, (4) Grup 4 (Çalış-SınaSına-Sına) 10 dakika çalışma kitapçı̆̆ında Güvenli İnternet Kullanımı konusuna çalışmış, sonrasında 2 dakikalık Oyalama 1 görevi verilmiş, devamında 10 dakika Test 1 uygulanmış, 2 dakikalık Oyalama 2 görevi verilmiş, 10 dakika Test 2 uygulanmış, sonrasında 5 dakikalık Oyalama 3 görevi verilmiş ve 10 dakika Test 3 uygulanmıştır. Çalışma kitapçığı ve sınama ile ilgili materyaller (testler ve oyalama görevleri) süreç sonunda öğrenenlerden toplanmıştır. İkinci hafta ise grupların öğrendikten uzun süre sonraki hatırlama performanslarını ölçmek için 10 dakika Test 3 uygulanmış ardından da süreç ile ilgili görüşlerini almak amacıyla tüm öğrenenlere "Güvenli İnternet Kullanımı konusunu öğrenmenizde gerçekleştirdiğiniz çalışma yönteminin nasıl bir etkisi olduğunu düşünüyorsunuz? Açıklayınız." sorusu yöneltilerek yanıtlamaları istenmiştir. Birinci haftanın uygulama süreci Şema 1'de, ikinci haftanın uygulama süreci ise Şema 2'de verilmiştir.

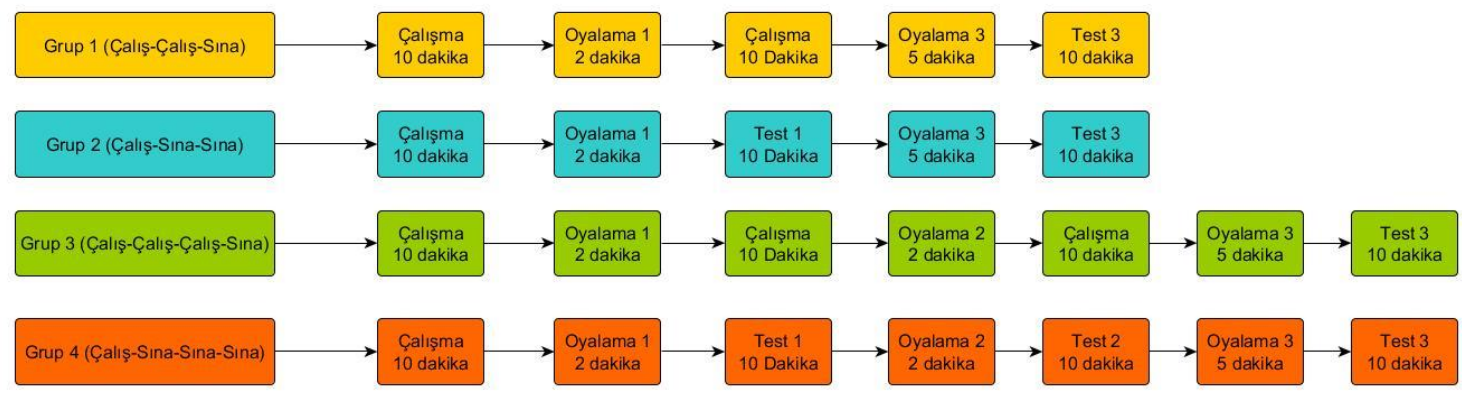

Şema 1. Birinci Hafta Uygulama Süreci

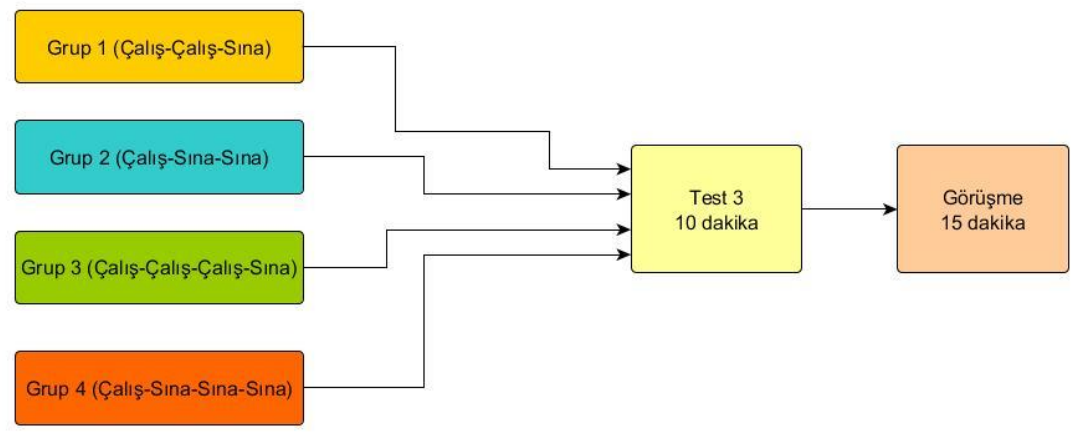

Şema 2. İkinci Hafta Uygulama Süreci

\section{Verilerin Analizi}

Öğrenenlerin 5 dakika ve 1 hafta sonraki hatırlama performanslarını ölçmek için Test 3 kullanılmıştır. Test 3'den alınabilecek en düşük puan 0 en yüksek puan 100 olacak şekilde belirlenmiştir. Test 3'nin değerlendirilmesinde kullanmak üzere öğrenenlerin hatırlamaları beklenen maddelerden oluşan bir kontrol listesi hazırlanmıştır. Kontrol listesindeki eksiksiz hatırlanan her bir madde 20 puan olarak değerlendirilmiştir. "Kendinize ya da bir başkasına ait kişisel bilgileri sosyal medya ortamlarında tanımadığınız kişilerle paylaşmayınız." maddesindeki gibi iki durum içeren maddelerin tamamının doğru hatırlanması 20 puan, bir 
kısmının hatırlanması ise 10 puan olarak değerlendirilmiştir. Hazırlanan kontrol listesi Ek 7'de, örnek bir değerlendirme Ek 8'de sunulmuştur. Öğrencilerin Test 3'e verdikleri yanıtlar iki puanlayıcı (birinci yazar ve bir bilişim teknolojileri ve yazılım öğretmeni) tarafından değerlendirilmiş ve puanlayıcılar arası uyum için Cohen's Kappa katsayısı hesaplanmıştır. Hesaplama sonucu Kappa Katsayısı 0.77 olarak bulunmuştur. Alan yazında Kappa katsayısının değerinin 0.75 ve üzeri olmasının mükemmel bir uyum olduğu, 0.40 ile 0.75 arasında olmasının iyi bir uyum olduğu, 0.40 ve altında olmasının ise zayıf bir uyum olduğu gösterdiği belirtilmektedir (Krippendorff, 1980). Buradan yola çıkarak puanlayıcılar arasında mükemmel bir uyumun olduğu söylenebilir.

Analizler SPSS programı kullanılarak gerçekleştirilmiştir. Verilerin yorumlanmasında anlamlılık düzeyi 0.05 olarak belirlenmiştir. Alan yazında verilerin normalliğinin sınanmasında One Simple Kolmogrov Smirnov testinden yararlanılabileceği ifade edilmektedir (Mirabella, 2006). Bu araştırma kapsamında da grupların 5 dakika ve 1 hafta sonraki hatırlama performanslarına ait verilerin normalliği One Simple Kolmogrov Smirnov testi ile sınanmıştır. Analiz sonuçlarına ilişkin değerler Tablo 1'de verilmiştir.

Tablo 1. Grupların 5 Dakika ve 1 Hafta Sonraki Performanslarına Ait Verilerin One Simple Kolmogrov Smirnov Testi Sonuçları

\begin{tabular}{|c|c|c|c|c|c|}
\hline & & $\begin{array}{c}\text { Grup } 1 \text { (Çalış- } \\
\text { Çalış-Sına) }\end{array}$ & $\begin{array}{l}\text { Grup } 2 \text { (Çalış- } \\
\text { Sina-Sına) }\end{array}$ & $\begin{array}{c}\text { Grup } 3 \text { (Çalış- } \\
\text { Çalış-Çalış-Sına) }\end{array}$ & $\begin{array}{c}\text { Grup } 4 \text { (Çalış- } \\
\text { Sına-Sına-Sına) }\end{array}$ \\
\hline \multirow{4}{*}{$\begin{array}{l}5 \text { dakika } \\
\text { sonra }\end{array}$} & Ortalama & 25,22 & 36,07 & 26,92 & 44,00 \\
\hline & ss & 22,937 & 28,589 & 24,620 & 27,080 \\
\hline & Kolmogorov-Smirnov Z & ,953 &, 823 & 1,153 & ,794 \\
\hline & Asymp. Sig. (p) &, $324 *$ &, $507 *$ &, $140 *$ &, $555^{*}$ \\
\hline \multirow{4}{*}{$\begin{array}{l}1 \text { hafta } \\
\text { sonra }\end{array}$} & Ortalama & 30,00 & 33,93 & 30,77 & 42,40 \\
\hline & ss & 20,449 & 27,126 & 24,645 & 26,969 \\
\hline & Kolmogorov-Smirnov Z & ,938 &, 576 & 1,058 & 677 \\
\hline & Asymp. Sig. (p) &, $342 *$ &, $895 *$ &, $213 *$ &, $749 *$ \\
\hline
\end{tabular}

Tablo 1 incelendiğinde grupların 5 dakika ve 1 hafta sonraki hatırlama performanslarına ait verilerin normal dağıldığı görülmektedir ( $p>0.05$ ). Normallik sayıltısı sağlandığı için araştırma sürecinde parametrik testler kullanılmıştır. Buna göre grupların öğrenme koşulunun (tekrar çalışma veya sınanma) uygulanmasından 5 dakika sonraki hatırlama performansları arasındaki karşılaştırmaları yapmak için ANOVA'dan, 1 hafta sonraki hatırlama performansları ile ilgili karşılaştırmaları yapmak için ANCOVA'dan ve grupların 5 dakika ve 1 hafta sonraki performanslarının nasıl değiştiği ile ilgili analizleri yapmak için Bağımlı Örneklem t testinden yararlanılmıştır. Anova için grupların varyanslarının homojen olup olmadığına bakılmış ve varyansların homojen olduğu bulunmuştur $(\mathrm{p}=0.568>0.05)$. Ancova içinse grupların varyanslarının homojenli ve gruplar içi regresyon eğimleri incelenmiştir. Grupların varyanslarının homojen olduğu $(p=0.257>0.05)$. ve gruplar içi regresyon eğimlerinin eşit olduğu bulunmuştur $(\mathrm{p}=0.971>0.05)$.

Öğrenenlerin sürece yönelik görüşlerini değerlendirmek için içerik analizi yönteminden yararlanılmıştır. Öğrencilerin görüşme sorusuna verdikleri cevaplar tekrar tekrar okunarak önemli yerlerin altı çizilmiş, alt ve üst temalar oluşturulmuştur. Buna göre öğrenenlerin verdikleri yanıtlar, öğrenme koşulunun motivasyon ve katılıma etkisi ve öğrenme koşulunun öğrenme performansına etkisi üst temaları ve olumlu/olumsuz görüş alt temaları altında toplanmıştır. Her bir gruba ilişkin görüşme verileri belirtilen bu kodlama yöntemi ışığında analiz edilmiştir.

\section{Bulgular}

\section{Birinci Araştırma Problemine İlişkin Bulgular}

Birinci araştırma problemi “Öğrenenlerin Güvenli İnternet Kullanımı konusunu öğrenmesinde öğrenmelerinde farklı öğrenme koşullarının (Çalış-Çalış-Sına, Çalış-Sına-Sına, Çalış-Çalış-Çalış-Sına ve Çalış-Sına-Sına-Sına) 
öğrenenlerin 5 dakika sonraki hatırlama performanslarına etkisi nedir?” şeklindedir. Bu bölümde öğrenen gruplarının 5 dakika sonraki hatırlama performanslarının karşılaştırılmasına yönelik analizler yapılmıştır. Güvenli İnternet Kullanımı konusuna ilişkin öğrenenlerin hatırlama performanslarının gruplara göre dağılımını gösteren grafik Şekil 1'de, öğrenenlerin 5 dakika sonraki hatırlama performanslarına ait analiz sonuçları Tablo 2'de yer almaktadir.

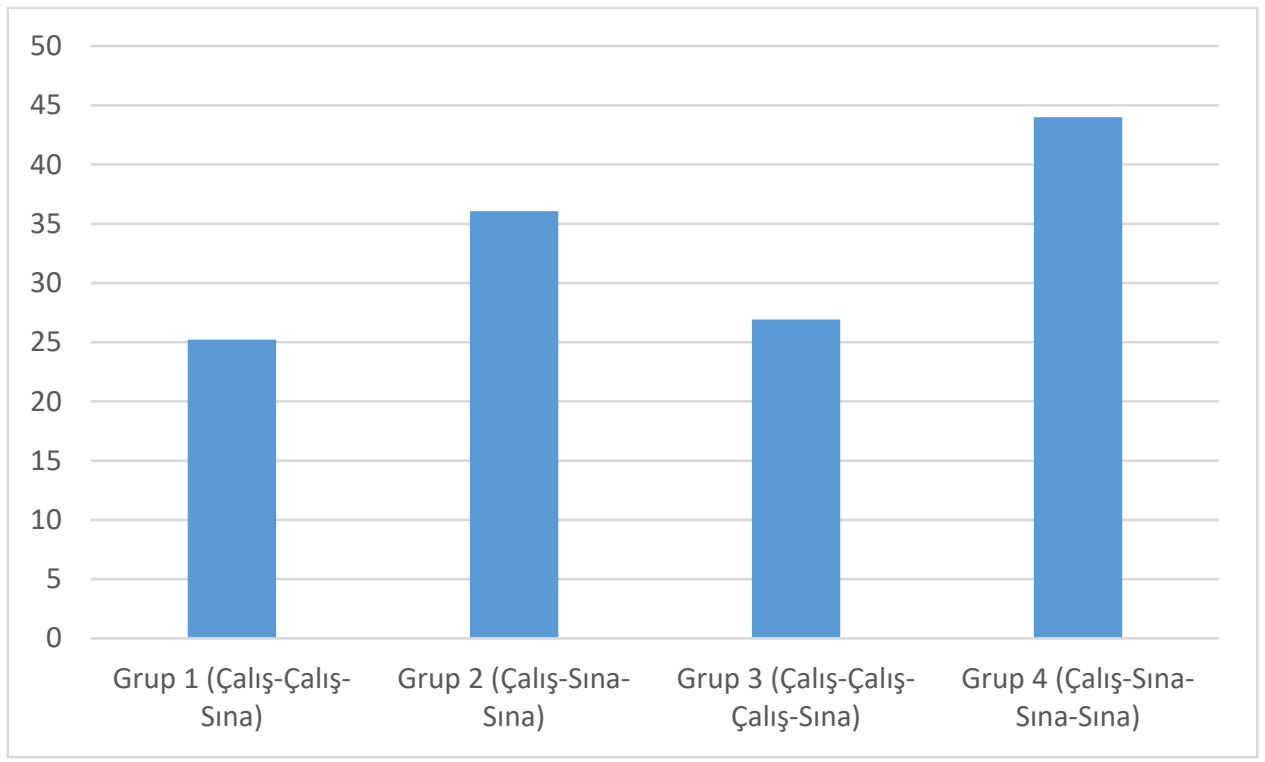

Şekil 1. Öğrenenlerin 5 Dakika Sonraki Hatırlama Performanslarının Gruplara Göre Dağılımı

Şekil 1'deki grafikte aktarıldığ üzere 5 dakika sonraki hatırlama performansı en yüksek olan grubun en çok sınav olan grup olduğu (Grup $4(\mathrm{M}=44)$ ), onu sırasıyla iki kere sınav olan (Grup $2(\mathrm{M}=36,07)$ ), en çok çalışan (Grup $3(M=26,92)$ ) ve en az çalışan (Grup 1(M=25,22)) grupların takip ettiği görülmektedir. Grupların hatırlama performansları arasında anlamlı bir farklılık olup olmadığına bakmak için ANOVA uygulanmıştır.

Tablo 2. Birinci Probleme İlişkin Öğrenenlerin 5 Dakika Sonraki Hatırlama Performanslarına Ait Verilerin ANOVA Sonuçları

\begin{tabular}{lccccc}
\hline & KT & df & KO & F & Sig. \\
Gruplar Arası & 5636,737 & 3 & 1878,912 & 2,773 & ,045* \\
Gruplar İçi & 66395,616 & 98 & 677,506 & & \\
Toplam & 72032,353 & 101 & & & \\
\hline
\end{tabular}

Tablo 2'ye göre grupların 5 dakika sonraki hatırlama performansları arasında anlamlı bir farklılık olduğu görülmektedir $(\mathrm{p}<0.05)$. Anlamlı farklılığın hangi gruplar arasında olduğunu görmek için LSD testi uygulanmıştır. Test sonucunda Grup 4'ün Grup $1(p=0,014<0,05)$ ve Grup 3'e $(p=0,021<0,05)$ göre daha iyi hatırlama performansı sergilediği ancak Grup 2 ile arasında herhangi bir farklılık olmadığı bulunmuştur.

\section{İkinci Araştırma Problemine İlişkin Bulgular}

İkinci araştırma problemi “Öğrenenlerin Güvenli İnternet Kullanımı konusunu öğrenmelerinde farklı öğrenme koşullarının (Çalış-Çalış-Sına, Çalış-Sına-Sına, Çalış-Çalış-Çalış-Sına ve Çalış-Sına-Sına-Sına) öğrenenlerin 1 hafta sonraki hatırlama performanslarına etkisi nedir?” şeklindedir. Güvenli İnternet Kullanımı konusuna ilişkin öğrenenlerin 1 hafta sonraki hatırlama performanslarına ait analiz sonuçları Tablo 3'te, öğrenenlerin hatırlama performanslarının gruplara göre dağılımını gösteren grafik Şekil 2'te yer almaktadır. 


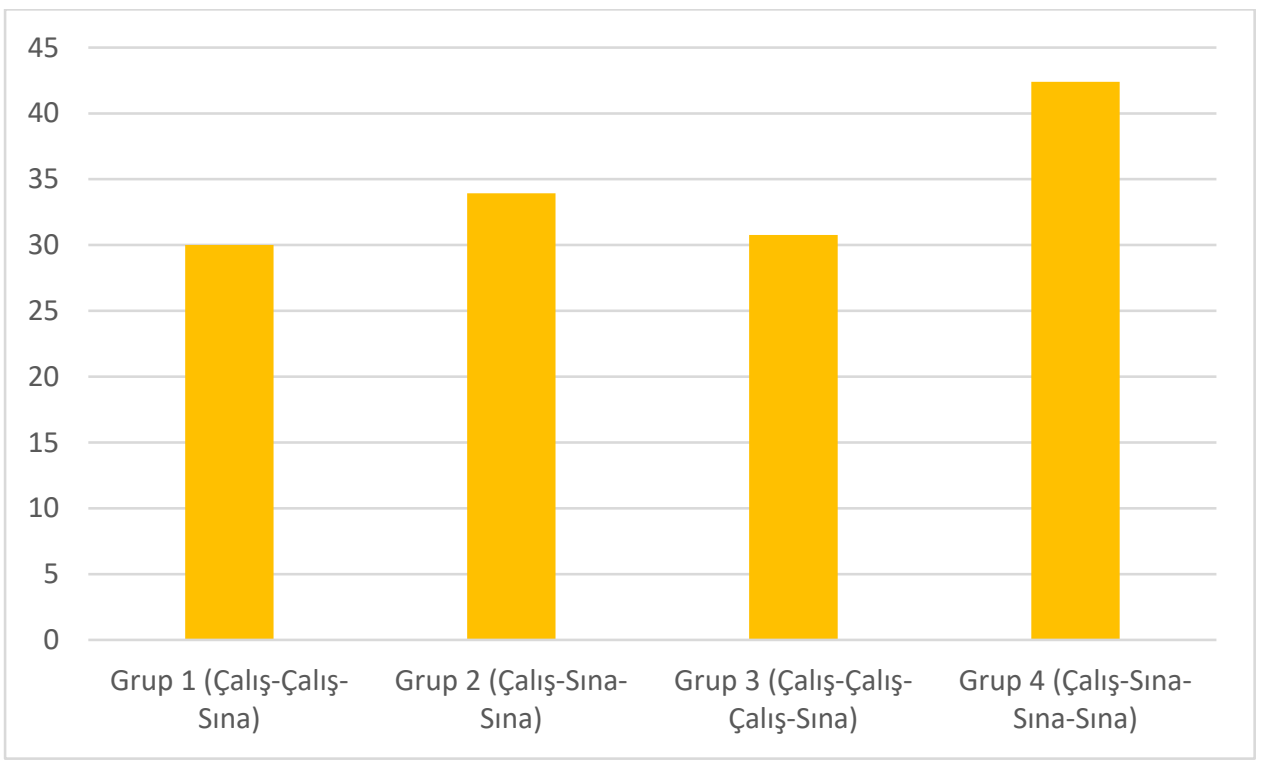

Şekil 2. Öğrenenlerin 1 Hafta Sonraki Hatırlama Performanslarının Gruplara Göre Dağılımı

Şekil 2'deki grafikte aktarıldığı üzere 1 hafta sonraki hatırlama performansı en yüksek olan grubun en çok sınav olan grup olduğu (Grup $4(\mathrm{M}=42,4))$, onu sırasıyla iki kere sınav olan (Grup $2(\mathrm{M}=33,929)$ ), en çok çalışan (Grup $3(M=30,769))$ ve en az çalışan (Grup $1(M=30))$ grupların takip ettiği görülmektedir. Grupların hatırlama performansları arasında anlamlı bir farklılık olup olmadığına bakmak için ANCOVA uygulanmıştır.

Tablo 3. İkinci Probleme İlişkin Öğrenenlerin 1 Hafta Sonraki Hatırlama Performanslarına Ait Verilerin ANCOVA Sonuçları

\begin{tabular}{lccccc}
\hline Varyans Kaynă̆ı & KT & df & KO & F & p \\
5 dakika sonra & 29229,744 & 1 & 29229,744 & 87,297 &, 000 \\
Grup & 199,566 & 3 & 66,522 &, 199 &, $897 *$ \\
Hata & 32478,729 & 97 & 334,832 & & \\
Toplam & 184200,000 & 102 & & & \\
\hline
\end{tabular}

Tablo 3'e göre öğrenenlerin 5 dakika sonraki hatırlama performansları kontrol altına alındığında 1 hafta sonraki hatırlama performansları arasında anlamlı bir farklılık olmadığı görülmektedir ( $p>0.05)$.

\section{Üçüncü Araştırma Problemine İlişkin Bulgular}

Üçüncü araştırma problemi “Öğrenenlerin Güvenli İnternet Kullanımı konusunu öğrenmesinde farklı öğrenme koşullarına (Çalış-Çalış-Sına, Çalış-Sına-Sına, Çalış-Çalış-Çalış-Sına ve Çalış-Sına-Sına-Sına) göre 5 dakika ve 1 hafta sonraki hatırlama performansları nasıl değişmektedir?" şeklindedir. Güvenli İnternet Kullanımı konusuna ilişkin öğrenenlerin hatırlama performanslarının gruplara göre dağılımını gösteren grafik Şekil 3'de, öğrenenlerin 5 dakika ve 1 hafta sonraki hatırlama performanslarına ait analiz sonuçları Tablo 4'de yer almaktadır. 


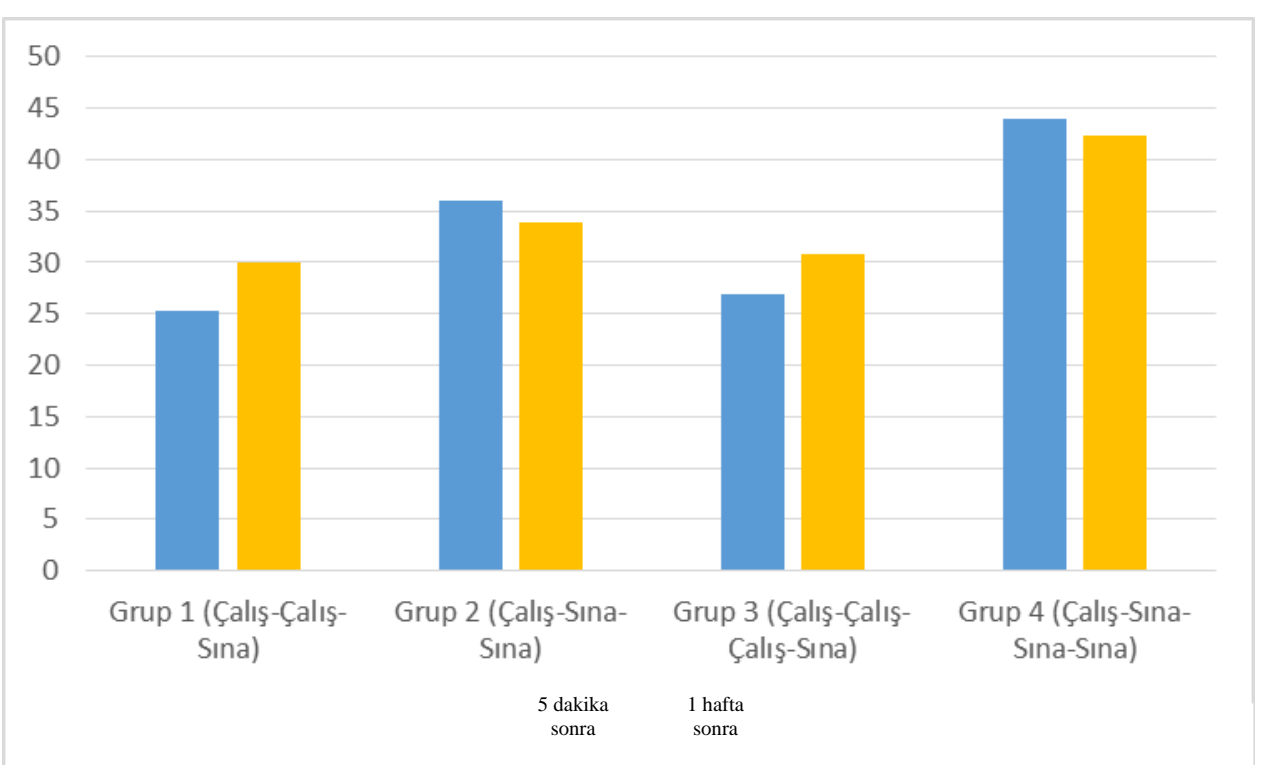

Şekil 3. Öğrenenlerin 5 Dakika ve 1 Hafta Sonraki Hatırlama Performanslarındaki Değişimin Gruplara Göre Dağılımı.

Şekil 3'teki grafikte aktarıldığ 1 üzere Grup 1 (Çalış-Çalış-Sına) ve Grup 3'teki (Çalış-Çalış-Çalış-Sına) öğrenenlerin 5 dakika sonraki hatırlama performansları (Grup $1(\mathrm{M}=25,217)$ ve Grup $3(\mathrm{M}=26,923))$ daha düşükken, 1 hafta sonraki hatırlama performanslarında Grup $1(\mathrm{M}=30)$ ve Grup 3'te $(\mathrm{M}=30,769)$ bir artış olduğu, Grup 2 (Çalış-Sına-Sına) ve Grup 4'teki (Çalış-Sına-Sına-Sına) öğrenenlerin 5 dakika sonraki hatırlama performansları (Grup $2(\mathrm{M}=36,071)$ ve Grup $4(\mathrm{M}=44))$ daha yüksekken, 1 hafta sonraki hatırlama performanslarında (Grup $2(\mathrm{M}=33,929)$ ve Grup $4(\mathrm{M}=42,4))$ bir azalma olduğu görülmektedir. Bu durumun istatistiksel açıdan anlamlı olup olmadığını incelemek üzere her bir grup için Bağımlı Örneklem $t$ testi uygulanmıştır.

Tablo 4 Üçüncü Probleme İlişkin Öğrenenlerin 5 Dakika ve 1 Hafta Sonraki Hatırlama Performanslarına Ait Verilerin Bağımlı Örneklem t testi Sonuçları

\begin{tabular}{lccccc}
\hline & $\bar{X}$ & ss & t & df & Sig. \\
Grup 1 (Çalış-Çalış-Sına) & $-4,783$ & 16,479 & $-1,392$ & 22 &, $178^{*}$ \\
Grup 2 (Çalış-Sına-Sına) & 2,143 & 19,693 &, 576 & 27 &, $570^{*}$ \\
Grup 3 (Çalış-Çalış-Çalış-Sına) & $-3,846$ & 20,799 &,- 943 & 25 &, $355^{*}$ \\
Grup 4 (Çalış-Sına-Sına-Sına) & 1,600 & 23,036 &, 347 & 24 &, $731^{*}$ \\
\hline
\end{tabular}

Tablo 4'e göre grupların 5 dakika ve 1 hafta sonraki hatırlama performanslarında anlamlı bir farklılık olmadığ 1 görülmektedir ( $\mathrm{p}>0.05)$.

\section{Dördüncü Araştırma Problemine İlişskin Bulgular}

Dördüncü araştırma problemi “Öğrenenlerin gerçekleştirilen öğrenme sürecine ilişkin görüşleri nedir?" şeklindedir. Bu araştırma problemi ile ilgili olarak öğrenenlere "Güvenli İnternet Kullanımı konusunu öğrenmenizde gerçekleştirdiğiniz çalışma yönteminin nasıl bir etkisi olduğunu düşünüyorsunuz? Açıklayınız.“ sorusu yöneltilmiş̧ir. Verilen yanıtlar incelenmiş ögrenme koşulunun motivasyon ve katılıma etkisi ve öğrenme koşulunun öğrenme performansına etkisi başlıkları altında sunulmuştur.

\section{Öğrenme koşulunun motivasyon ve katılıma etkisi}

Bu başlık altında öğrenenlerin öğrenme koşulu ile ilgili verdikleri yanıtların analizleri paylaşılmıştır. Verilen yanıtlar incelendiğinde öğrenenlerin büyük bir kısmı (Grup 1=21 kişi, Grup 2=23 kişi, Grup 3=22 kişi ve Grup 
$4=20$ kişi) gerçekleşen öğrenme sürecinin motivasyon ve derse katılımlarını olumlu yönde etkilediğini belirtirken, çok az bir kısmı (Grup 1=2 kişi, Grup 2=3 kişi, Grup $3=0$ kişi ve Grup 4= 5 kişi) gerçekleşen öğrenme sürecinin motivasyon ve derse katılımları üzerinde etkili olmadığı yönünde görüş belirtmiştir. Öğrenenlerin bazıları ise herhangi bir görüş bildirmemiştir (Grup $1=2$ kişi, Grup $2=4$ kişi, Grup $3=4$ kişi).

Yukarıda aktarıldığı üzere tüm gruplardaki öğrenenlerin büyük bir çoğunluğunun (86 kişi) öğrenme sürecinin motivasyon ve derse katılımlarını olumlu yönde etkilediğini düşündükleri görülmektedir. Uygulanan araştırma desenin öğrenenlere aktif oldukları bir süreç deneyimleme imkânı sunmasının öğrenenlerin süreç ile ilgili olumlu düşünceler oluşturmasında etkisi olabileceği söylenebilir. Bu yönde görüş bildiren öğrenenlerden bazılarının görüşleri aşağıda verilmiştir:

Grup 1 (Çalış-Çalış-Sına): "Bu yöntem bende etkili oldu, derse katılımım arttı. Ben bu uygulamadan memnun oldum...", "Iyi etkiledi çünkü Güzel bir çalışmaydl, ĕglenceliydi..."

Grup 2 (Çalış-Sına-Sına): “Etkili oldu ayrıca çok ĕglenceliydi...”, "Daha iyi etkiledi çünkü eğlenerek ögrenmek en iyi şeydir.,"

Grup 3 (Çalış-Çalış-Çalış-Sına): “İyi etkiledi. Hep böyle etkinlik olsaydı. Beni iyi etkiledi...”, "Benim için çok faydalı bir çalışma oldu. Ben bu çalışmanın hep olmasını isterim."

Grup 4 (Çalış-Sına-Sına-Sına): “Çok etkili. Bana çok faydalı oldu...”, “Bu yöntem bana göre iyi bir yöntem olmuş. Çok ĕ̆lenceli ..."

\section{Öğrenme koşulunun öğrenme performansına etkisi}

Bu başlık altında öğrenenlerin öğrenme koşulunun (sınanmak veya çalışmak) öğrenme performanslarına etkisi ile ilgili verdikleri yanıtların analizleri paylaşılmıştır. Verilen yanıtlar incelendiğinde öğrenenlerin büyük bir kısmının (Grup 1 = 19 kişi, Grup $2=24$ kişi, Grup $3=21$ kişi ve Grup $4=21$ kişi) gerçekleşen öğrenme sürecinin öğrenmelerini olumlu yönde etkilediğini belirttiği saptanmıştır. Gerçekleşen öğrenme sürecinin öğrenmelerini olumsuz yönünde etkilediğine dair görüş bildiren öğrenenlerin ise oldukça az olduğu(Grup $1=1$ kişi, Grup $2=2$ kişi, Grup 3 = 0 kişi ve Grup $4=4$ kişi) belirlenmiş̧tir. Öğrenenlerin bir kısmı ise herhangi bir görüş bildirmemiştir (Grup 1 = 3 kişi, Grup 2 = 2 kişi, Grup $3=5$ kişi).Öğrenenlerden bazılarının görüşleri aşağıda paylaşılmıştır:

Grup 1 (Çalış-Çalış-Sına): “...Öğrenmem daha kolay oldu.”, “...bize çok bilgi verdi. Çok kolay öğrendim.”

Grup 2 (Çalış-Sına-Sına): “... Bu yöntemle daha iyi öğrendim ve çok kolay geldi.”,”...Bu etkinlik sayesinde daha iyi anladım ve daha iyi ögrendim.”

Grup 3 (Çalış-Çalış-Çalış-Sına): “...Bu şekilde daha kolay öğrendim. ”, “...Daha rahat öğrendim.”

Grup 4 (Çalış-Sına-Sına-Sına): “...Bu çalışmanın bana faydası olduğunu düşünüyorum. Daha iyi öğrendim. ”, "Bu yöntem bana göre iyi bir yöntem olmuş... Bu sayede daha kolay ögrrendiğimi düşünüyorum.”

Diğer taraftan öğrenme koşulu sınanmak olan Grup 4’te öğrenme sürecine ilişkin olumsuz görüş belirten öğrenenlerin art arda sınav olmayı sıkıcı buldukları dikkati çekmektedir. Grup 4'teki öğrenen görüşünden yola çıkarak test uygulamasının sayısının artırılmasının küçük yaş grubundaki öğrenenleri olumsuz yönde etkileyebileceği söylenebilir. Bu yönde görüş bildiren öğrenenlerden bazılarının görüşleri aşağıda verilmiştir:

"Biraz etkisi oldu. Sürekli soru cevaplamak sıkıcıydı. Daha iyi ögrendim gibi ama daha da zor gibi... Yani bu konuda biraz aklım karıştı."

"Bana etkili gelmedi. Çünkü soruları çözmek sıkıcıydı..."

\section{Tartışma ve Sonuç}

$\mathrm{Bu}$ araştırma kapsamında ortaokul öğrencilerinin Güvenli İnternet Kullanımı konusunu öğrenmelerinde öğrenme koşulunun (tekrar sınama veya tekrar çalışma) farklı kombinasyonlarının (Çalış-Çalış-Sına, Çalış-SınaSına, Çalış-Çalış-Çalış-Sına ve Çalış-Sına-Sına-Sına) öğrenenlerin hatırlama performansları üzerine etkisi araştırılmıştır. Araştırma sonucunda 5 dakika sonraki hatırlama performansı açısından en çok sınanan grubun (Grup 4) çalışma gruplarına (Grup 1 ve Grup 3) göre daha iyi performans sergilediği bulunmuştur. Ancak en çok 
sınanan grup (Grup 4) ve diğer sınama grubu (Grup 2) arasında hatırlama performansı açısından bir farklılık bulunamamıştır. Elde edilen bu bulgunun Roediger \& Karpicke'nin (2006b) çalışmasıyla çeliştiği görülmektedir. Yazarlar çalışmalarında en çok çalışan grubun öğrendikten 5 dakika sonraki hatırlama performansında daha iyi olduğunu bulmuşlardır.

Grupların 1 hafta sonraki performansları ve 5 dakika ve 1 hafta sonraki performanslarındaki değişim incelendiğinde istatistiksel açıdan anlamlı bir farklılık bulunamamıştır. Bu durum alan yazındaki bazı çalışmalarla benzerlik göstermektedir (Atabek Yiğit vd., 2014; Demiraslan Çevik \& Çoban, 2016). Bu çalışmalarda da uzun süreli hatırlama performansı açısından tekrar çalışma ve sınama grupları arasında bir farklılık bulunamamıştır. Ancak alan yazında yürütülen bazı çalışmalarda (Örneğin, Butler vd., 2007; Butler \& Roediger, 2007; McDaniel vd., 2007a; McDaniel vd., 2007b; Roediger \& Karpicke 2006b) öğrenme koşulu sınanmak olan grupların öğrenilen bilginin hatırlanmasında daha iyi performans sergilediği görülmektedir. Sınama etkisinin temel var sayımı öğrenilen bilginin sınanmasının hatırlamayı artıracağı yönündedir. Chan, Wilford \& Hughes (2012) bu durumun yanlış bilginin geri çağrılmasını da artırabileceğine dikkati çekmektedirler. Bu çalışma kapsamında öğrenenlere yanlış ya da eksik cevaplarına yönelik dönüt sağlanmamıştır. Bu durum göz önünde bulundurulduğunda, yanlış bilgi etkisi olarak adlandırılan bu varsayımın sınama etkisinin ortaya konamama nedenlerinden biri olabileceği düşünülmektedir.

Psikoloji alanında sınama etkisinin ortaya konduğu çalışmalarda tanıma ve geri çağırma testlerinin kullanıldığı görülmektedir. Oysa eğitim ortamında birçok farklı test türü kullanılmaktadır. Roediger \& Karpicke (2006b) bu iki alandaki çalışmaları inceleyerek bu farka dikkati çekmiş ve uygulanan test türünün sınama etkisinin ortaya çıkmasında bir rolünün olabileceğini belirtmişlerdir. Yazarlar ayrıca eğitim ortamında sınama etkisinin ortaya çıkmasında farklı test türlerinin bir etkisinin olup olmadığının henüz yeteri kadar araştırılmadığına dikkati çekmektedirler. Bu alanda sınama etkisinin araştırıldığ 1 çalışmalarda kısa cevaplı, çoktan seçmeli, doğru yanlış ve boşluk doldurma testlerinin kullanıldığı görülmektedir (Örneğin, Dobson \& Perez, 2016; Larsen, Butler ve Roediger, 2009; Roediger \& Karpicke, 2006a). Gerçekleştirilen bu çalışmada diğer çalışmalardan farklı olarak kullanılan test materyallerinde öğrenenlerin verilen örnek olayı incelemeleri ve onunla ilgili maddeyi hatırlamaları beklenmiştir. Bu şekilde hazırlanan testlerin öğrenenlerin verilen durumun analizini yapmasını ve ilgili cevapla eşleştirmesini gerektirdiğinden nispeten daha zor olduğu söylenebilir. Bu durumun da sınama etkisinin ortaya konamamasının bir nedeni olabileceği düşünülmektedir

Daha önce belirtildiği üzere araştırma sonucunda tekrar sınama ve çalışma gruplarında yer alan öğrenenlerin uzun süreli hatırlama performansları açısından bir farklılık bulunamamıştır. Her iki grupta yer alan öğrenenlerin de gerçekleştirdikleri öğrenme sürecinin motivasyon ve derse katılıma olumlu bir etkisi olduğunu ve daha kolay öğrenmelerini sağladığını belirttikleri görülmüştür. Ulaşılan bu sonucun uygulanan araştırma deseninin öğrenenlere aktif oldukları bir öğrenme süreci deneyimleme imkânı sunmasından kaynaklanmış olabileceği söylenebilir. Ayrıca çalışma grubunda yer alan öğrenenlerin bu şekilde düşünmesinin bir diğer nedeni olarak öğrenenlerin sınavlara daha çok materyali okuyarak çalışmayı tercih etmeleri gösterilebilir (Atebik Yiğit vd., 2014). Çalışmada beklenilenin aksine uzun süreli hatırlamada en çok sınanan grup daha iyi hatırlama performansı sergilememiştir. Bu grupta öğrenme sürecinin etkili olmadığını ve daha zor öğrendiklerini belirten öğrenenlerin art arda sınav olmayı sıkıcı buldukları dikkati çekmektedir. Buradan yola çıkarak test uygulamasının sayısının artırılmasının küçük yaş grubundaki öğrenenleri olumsuz yönde etkileyebileceği söylenebilir. Ancak bu durumun geçerliliğinin anlaşılabilmesi için benzer çalışmaların yapılmasına ihtiyaç vardır.

Aktarıldığı üzere bu çalışmada sınama etkisine yönelik uzun süreli hatırlamada istatistiksel açıdan anlamlı bulgular elde edilememiştir. Bunların nedenleri yukarıda açıklanmaya çalışılmıştır. Özellikle küçük yaş grubunda sınama etkisi ile ilgili çalışmaların sınırlı olduğu ve öğrenme koşulunun (tekrar sınama veya tekrar çalışma) farklı kombinasyonlarının karşılaştırıldığı çalışmaların az olduğu görülmektedir. İleriki çalışmalar için araştırma konusu olarak bunların üzerinde durulabileceği, bu çalışmanın daha büyük bir öğrenen grubu ile tekrarlanabileceği ve yine küçük yaş grubunda farklı testlerle (kısa cevaplı, çoktan seçmeli, örnek olay vb.) gerçekleştirilen çalışmalarla sınama etkisinin nasıl sonuçlar vereceğinin araştırılması önerilmektedir. 


\section{References}

Agarwal, P. K., Karpicke, J. D., Kang, S. H., Roediger, H. L., \& McDermott, K. B. (2008). Examining the testing effect with open-and closed-book tests. Applied Cognitive Psychology, 22(7), 861-876.

Aslan, A., \& Karakuş Yilmaz, T. (2017). Türkiye'de güvenli internet kullanimina yönelik gerçekleştirilen uygulamalar [Practices developed towards safer internet use in turkey]. Dumlupinar University Journal of Social Science, (53).

Atabek Yigit, E., Balkan Kiyici, F., \& Cetinkaya, G. (2014). Evaluating the testing effect in the classroom: An effective way to retrieve learned information. Eurasian Journal of Educational Research, 54, 99-116.

Atabek Yiğit, E., \& Balkan Kıyıcı, F. (2016). Öğrenilen bilgilerin hatırlanmasında sınavların etkisi [Effects of tests to recall the learned information]. Journal of Kirsehir Education Faculty, 17(1).

Bangert-Drowns, R. L., Kulik, J. A., \& Kulik, C. L. C. (1991). Effects of frequent classroom testing. The Journal of Educational Research, 85(2), 89-99.

Butler, A. C., Karpicke, J. D., \& Roediger, H. L. (2007a). The effect of type and timing of feedback on learning from multiple-choice tests. Journal of Experimental Psychology: Applied, 13(4), 273.

Butler, A. C., \& Roediger, H. L. (2007b). Testing improves long-term retention in a simulated classroom setting. European Journal of Cognitive Psychology, 19(4-5), 514-527.

Büyüköztürk, Ş., Kılıç Çakmak, E., Akgün, Ö. E., Karadeniz, Ş., \& Demirel, F. (2013). Bilimsel araştırmanın temelleri [Scientific research methods]. Ankara: Pegem Akademi.

Carpenter, S. K., Pashler, H., \& Cepeda, N. J. (2009). Using tests to enhance 8th grade students' retention of US history facts. Applied Cognitive Psychology, 23(6), 760-771.

Chan, J. C., Wilford, M. M., \& Hughes, K. L. (2012). Retrieval can increase or decrease suggestibility depending on how memory is tested: The importance of source complexity. Journal of Memory and Language, 67(1), 78-85.

Çevik, Y. D., \& Çoban, T. (2016). Testing effect in learning digital property and cyber ethics. SDU International Journal of Educational Studies, 3(1), 84-99.

Darley, C. F., \& Murdock, B. B. (1971). Effects of prior free recall testing on final recall and recognition. Journal of Experimental Psychology, 91, 66-73.

Dobson, J., \& Perez, J. (2016). The Testing Effect Varies with Spaced Versus Massed Learning of Skeletal Muscle Information. The FASEB Journal, 30 (1 Supplement), 776-15.

Ersoy, A., \& Yılmaz, F. (2015). Çocuklarin internette araştirma yaparken karşilaştiklari olumsuz deneyimleri ve bu deneyimlere yönelik tepkileri [Children's negative experiences faced on the internet whilst researching their homework and their responses to these experiences]. Electronic Turkish Studies, 10(11).

Heesen, J. (2012). Computer and Information Ethics - Chadwick, Ruth Encyclopedia of Applied Ethics (Second Edition) (pp. 538-546). San Diego: Academic Press.

Karakuş, T., Çağıltay, K., Kaşıkcı, D., Kurşun, E., \& Ogan, C. (2014). Türkiye ve avrupa'daki çocukların internet alışkanlıkları ve güvenli internet kullanımı [Internet habits and safe internet use of children in turkey and europe]. Ĕ̈itim ve Bilim, (171).

Korkmaz, M., \& Esen, B. K. (2016). Güvenli internet kullanımı konusunda uygulanan akran eğitiminin ergenler üzerindeki etkisi [The effects of peer-training about secure internet use on adolescents]. Türk Psikolojik Danışma ve Rehberlik Dergisi, 4(38).

Köse, N. (2016). Ergenlerde internet bağımlılığının yaşam doyumuna etkisi [The effect of internet addiction in adolescents on life satisfaction]. Elektronik Mesleki Gelişim ve Araştırmalar Dergisi, 4(1).

Krippendorff, K. (1980). Content analysis. Beverly Hills. California: Sage Publications. 
Larsen, D. P., Butler, A. C., \& Roediger, H. L. (2009). Repeated testing improves long-term retention relative to repeated study: a randomised controlled trial. Medical Education, 43(12), 1174-1181.

Meral, D., \& Bahar, H. H. (2016). Ortaöğretim öğrencilerinde problemli internet kullanımının yalnızlık ve psikolojik iyi oluş ile ilişkisinin incelenmesi [Investigating the relationship between problematic internet use and psychological well being and loneliness in secondary education students]. Journal of Education Faculty, 18(2), 1117-1134.

McDaniel, M. A., Kowitz, M. D., \& Dunay, P. K. (1989). Altering memory through recall: The effects of cueguided retrieval processing. Memory and Cognition, 17, 423-434.

McDaniel, M. A., Anderson, J. L., Derbish, M. H., \& Morrisette, N. (2007a). Testing the testing effect in the classroom. European Journal of Cognitive Psychology, 19(4-5), 494-513.

McDaniel, M. A., Roediger, H. L., \& McDermott, K. B. (2007b). Generalizing test-enhanced learning from the laboratory to the classroom. Psychonomic Bulletin \& Review, 14(2), 200-206.

McDermott, K. B., Agarwal, P. K., D'antonio, L., Roediger III, H. L., \& McDaniel, M. A. (2014). Both multiple-choice and short-answer quizzes enhance later exam performance in middle and high school classes. Journal of Experimental Psychology: Applied, 20(1), 3.

Mirabella, J. (2006). Hypothesis testing with SPSS: A non-statistician's guide \& tutorial. Retrieved August, 15, 2006.

Morrison, C. M., \& Gore, H. (2010). The relationship between excessive Internet use and depression: a questionnaire-based study of 1,319 young people and adults. Psychopathology, 43(2), 121-126.

Roediger, H. L., \& Karpicke, J. D. (2006a). The power of testing memory: Basic research and implications for educational practice. Perspectives on Psychological Science, 1(3), 181-210.

Roediger, H. L., \& Karpicke, J. D. (2006b). Test-enhanced learning taking memory tests improves long-term retention. Psychological science, 17(3), 249-255.

Roediger, H. L., Putnam, A. L., \& Smith, M. A. (2011). Ten benefits of testing and their applications to educational practice. In J. Mester, \& B. Ross (Eds.), The psychology of learning and motivation: Cognition in education (pp. 1-36). Oxford: Elsevier.

Şişman, M. (2011). Eğitim bilimine giriş [Introduction to educational science]. Pegem Akademi.

Takemura, T., \& Umino, A. (2009). A quantitative study on Japanese Internet users' awareness to information security: necessity and importance of education and policy. World Academy of Science, Engineering and Technology, 60, 638-644.

Tekin, A., \& Polat, E. (2014). Technology policies in education: Turkey and several other countries. Journal of Theory and Practice in Education, 10(5), 1254-1266.

Terry, W. S. (2011). Öğrenme \& Bellek: Temel İlkeler, Süreçler ve İşlemler. Çev., Banu Cangöz. Ankara: Anı Yayınlar1.

TÜİK. (2013). Türkiye İstatistik Kurumu. 06-15 yaş grubu çocuklarda bilişim teknolojileri kullanımı ve medya [In the age group of 06-15 years, the use of information technology and media]. [Çevrim-içi: http://www.tuik.gov.tr/PreHaberBultenleri.do?id=15866, Erişim Tarihi: 07.12.2016.]

TÜİK. (2016). Türkiye İstatistik Kurumu. Hane halkı bilişim teknolojileri kullanım araştırması [Household information technologies usage survey]. [Çevrim-içi: http://www.tuik.gov.tr/PreHaberBultenleri.do?id=21779, Erişim Tarihi: 07.12.2016.]

Whitten, W. B., \& Bjork, R. A. (1977). Learning from tests: Effects of spacing. Journal of Verbal Learning and Verbal Behavior, 16(4), 465-478. 


\section{Ekler}

\section{Ek 1}

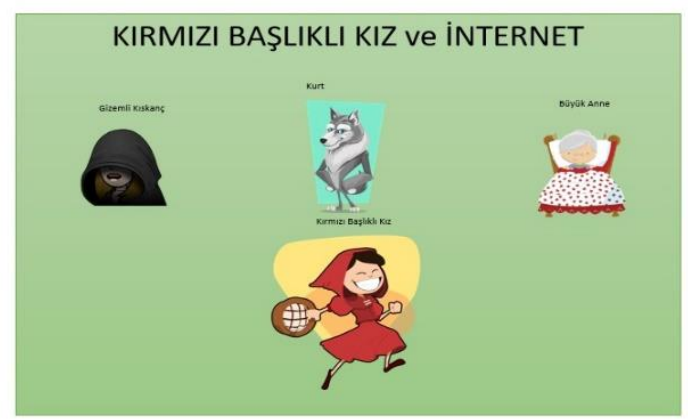

1) “Kırmızı başıklı kız her zamanki gibi okuldan eve döner ödevlerini bitirir ve bilgisayarda zaman geçirmek için bilgisayarını açar. En sevdiği oyun sitesine girer ve her zaman severek oynadığı elma düşürme oyununu aramaya başlar. 0 sırada gözüne sitedeki bir link çarpar: "Bedava Cep Telefonu Kazandınız. Hediyenizi Almak için Tıklayın!”. Kırmızı başııkı kız sevinçten havalara uçar. Uzun zamandır ailesinden bir cep telefonu istemektedir ve sonunda cep telefonu olduğunu düş̧unerek linke tıklar. Ancak tıklar tıklamaz bir şeyler ters gitmeye başlar. Bilgisayarı kendi kendini kapatmaktadır. Kırmızı başıkıı kız birkaç kere bilgisayarını yenide başlatmayı dener ama işe yaramaz. Sorunun ne olduğunu bilemeden bilgisayardan sıkılır ve tableti eline alır."

Sizce burada kırmızı başıkı kız güvenli internet kullanımı ile ilgili öğrendiğiniz maddelerden hangisine dikkat etmemiştir? Kırmızı başlıklı kııın yaptığı hangi davranıştan dolayı dikkat etmediğini düşündünüz?

Siz olsaydınız ne yapardınız?

2) "Kırmızı başıkı kızın hocası bilgisayar dersindeki etkinlikler erken bitince 5 dakikalık serbest zaman verir. Kırmızı başıkıı kız da bu zamanı facebookta geçirmeye karar verir. Facebook'a girince yeni bir arkadaşlı isteğini fark eder. İstek gönderen kişiyi tanımamaktadır ancak "oo yeni bir arkadaşık isteği, popülerliğim artıyor!” diyerek isteği kabul eder. Tehlikenin farkında değildir. Arkadaşlık isteği gönderen aslında kötü niyetli kurttur. Başka bir isim ve fotoğraf kullanarak bir hesap oluşturmuştur ve kırmızı başıkı kızı takip etmek istemektedir. "

Sizce burada kırmııı başıkı kız güvenli internet kullanımı ile ilgili öğrendiğiniz maddelerden hangisine dikkat etmemiştir? Kırmızı başlıklı kızın yaptığı hangi davranıştan dolayı dikkat etmediğini düşündünüz?

Siz olsaydınız ne yapardınız? 
3)“Kırmızı başlıklı kız fotoğraf çekmeyi ve fotoğraflarını paylaşmayı çok sevmektedir. Bir gün yine kendi fotoğraflarını çeker ve paylaşır. Ancak paylaşımlarının gizlilik ayarlarını kontrol etmemiştir. Tüm paylaşımları herkese açıktır. Kırmızı başıkı kız farkında değildir ama kırmııı başlığıı kıskanan bir yabancı onu an ve an takip etmektedir. Her paylaştığını kendi fotoğrafı gibi alıp paylaşmaktadır."

Sizce burada kırmızı başıkı kız güvenli internet kullanımı ile ilgili öğrendiğiniz maddelerden hangisine dikkat etmemiştir? Kırmızı başıkıı kızın yaptığı hangi davranıştan dolayı dikkat etmediğini düşündünüz?

Siz olsaydınız ne yapardınız?

4)"Kırmızı başıkılı kız en sevdiği çizgi film kahramanı olan Winx ile ilgili sayfalara bakmaktadır. Baktığı sayfalardan birinde "Winx oyuncaklarına sahip olmak isteyenler mesaj atsın." şeklinde bir yorum görmüştür. Hemen kullanıcıya mesaj atar. Mesaj attığı kişi de kırmızı başıklı kıza kredi kartı bilgilerini mesaj atması şartıyla 3 lira gibi küçük bir ücrete istediği Winx oyuncalarına sahip olabileceğini söyler. Kırmızı başlıkı kız da heyecanla karşısındaki kişinin isteğini yerine getirir."

Sizce burada kırmızı başıkı kız güvenli internet kullanımı ile ilgili öğrendiğiniz maddelerden hangisine dikkat etmemiştir? Kırmızı başıkı kızın yaptığı hangi davranıştan dolayı dikkat etmediğini düşündünüz?

Siz olsaydınız ne yapardınız?

5)"Kırmııı başıılı kız internette dolaşırken bir sürü olumsuz durumla karşılaşmıştır. Tanımadı̆̆ı birinden gelen arkadaşık isteğini kabul etmiş, yine ailesine ait olan kişisel bilgileri başkalarıyla paylaşmıł̧ ve bunun gibi birçok durum. Ancak bu durumları ne öğretmeni ne de ailesi ile paylaşmamıştır. Hatta bunların birçoğunun olumsuz durumlara neden olabileceğinin farkında bile değildir."

Sizce burada kırmızı başıkıı kız güvenli internet kullanımı ile ilgili öğrendiğiniz maddelerden hangisine dikkat etmemiştir? Kırmızı başıkıı kıın yaptığı hangi davranıştan dolayı dikkat etmediğini düşündünüz?

Siz olsaydınız ne yapardinı? 


\section{Ek 2}

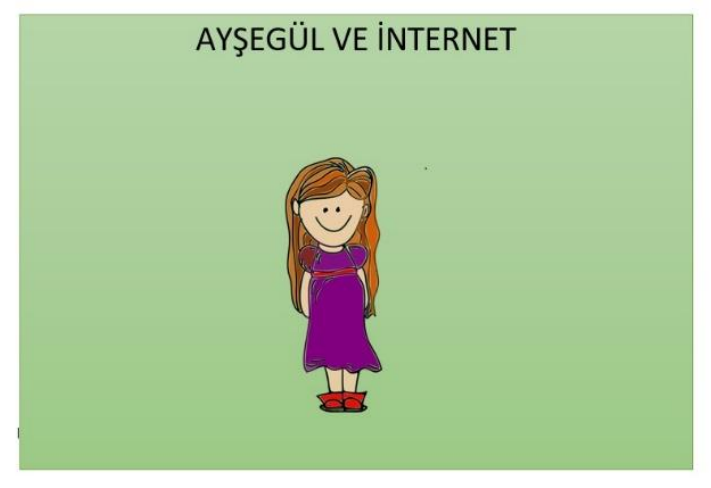

1) “Ayşegül heyecanlı bir şekilde okuldan eve gelir. Her zamanki gibi yemeğini yer ve ödevlerini bitirir. Öğretmeni ailesindeki kişileri tanıtan bir ödev yapmasını istemiştir. Ayșegül ödevini ailesindekilerin fotoğraflarını kullanarak hazırlamayı planlamaktadır. Aile albümünü almak için çekmeceye gider ve orada kendisine ve ailesindeki diğer kişilere ait nüfus cüzdanlarını bulur. Babasının nüfus cüzdanındaki fotoğrafının oldukça eski ve komik olduğunu düşünür. Hemen nüfus cüzdanının bir fotoğrafını çeker ve bilgisayara oturduğunda bu fotoğrafı herkese açık olarak paylaşır. Aradan bir hafta geçer. Ayșegül okuldan eve geldiğinde babasını çok üzgün görür. Sebebini sorduğunda birilerinin kimlik bilgilerini kullanarak onu zor durumda bıraktığını ve nasıl olup ta kimlik bilgilerinin başkalarının eline geçtiğini anlamadığını söyler..."

Sizce burada Ayşegül güvenli internet kullanımı ile ilgili öğrendiğiniz maddelerden hangilerine dikkat etmemiştir? Ayşegül'ün yaptığı hangi davranıştan dolay dikkat etmediğini düşündünüz?

Siz olsaydınız ne yapardınız?

2) "Bilgisayar dersindeki etkinlikleri erken bitmiştir. Öğretmenleri 10 dakikalık serbest zaman tanımıştır. Ayșegül de bu zamanı en sevdiği çizgi film kahramanı olan Ay Savaşçısı'nın resimlerine bakarak geçirmeye karar verir. Girdiği bir sitede resimler arasında gezinirken "Bedava Ay Savaşçısı Oyuncağı Kazandınız. Almak için Tıklaxın!"” diye yanıp sönen bir link görür. Ay Savaşçısı oyuncağını almak için sabırsızlıkla linke tıklar. Linke tıkladığında karşısına bir form gelir ve bu formda Adı, Soyadı, TC kimlik numarası, Adresi ve Kredi Kartı bilgileri sorulmaktadır. Ayşegül kredi kartı bilgileri hariç tüm bilgileri doldurur. Kendine ait kredi kartı olmadığı için bir tek o alan boş kalmıştır ve tamamlaya tıkladığında hata vermektedir. Ayşegül o gün dersi biter bitmez eve gider hemen annesinin kredi kartını alır ve aynı siteye girip eksiksiz bir şekilde bilgileri doldurur..."

Sizce burada Ayşegül güvenli internet kullanımı ile ilgili öğrendiğiniz maddelerden hangisine dikkat etmemiştir? Ayşegül'ün yaptığı hangi davranıştan dolay dikkat etmediğini düşündünüz?

Siz olsaydınız ne yapardınız?

3)"Ayşegül ve kardeşi tablette oyun oynamaktadır. Kardeşi kaybedince sıra Ayşegül'e geçer ve heyecanla oyununa başlar. O sırda facebook'tan bir bildirim gelir. Bir arkadaşlık isteği almıştır ancak ekleyen kişiyi tanımamaktadır. Ayşegül isteği kabul eder ve oyununa geri döner."

Sizce burada Ayşegül güvenli internet kullanımı ile ilgili öğrendiğiniz maddelerden hangisine dikkat etmemiştir? Ayşegül'ün yaptığı hangi davranıştan dolayı dikkat etmediğini düşündünüz?

Siz olsaydınız ne yapardınız? 
4) “Ayşegül bu hafta internette bir sürü şey yaşamıştır. Ne kadar yorucu ve üzücü bir hafta olduğunu düşünür. Hala başına gelenleri kimse ile paylaşmamıştır. Hatta kimseyle paylaşmadığı için yaşadığı bazı kötü durumların farkında bile değildir..."

Sizce burada Ayşegül güvenli internet kullanımı ile ilgili öğrendiğiniz maddelerden hangisine dikkat etmemiştir? Ayşegül'ün yaptığı hangi davranıştan dolayı dikkat etmediğini düşündünüz?

Siz olsaydınız ne yapardınız? 


\section{Ek 3}

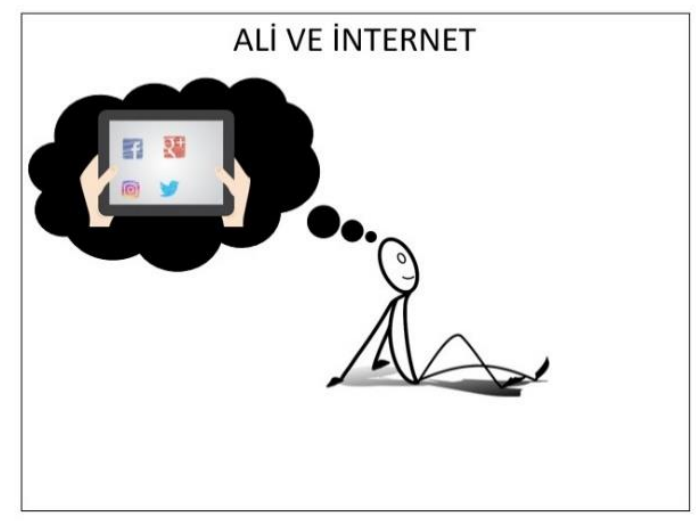

1) ${ }^{a}$ Ali Facebook, Twitter ve Instagram gibi sosyal medya ortamlanı kullanmaktadır. Ali bir gün çok gūzel bir resim çizer ve bunu paylaşmak ister. Ancak paylaşımlarını herkese açıı bir şekilde yapmaktadır. Resmi çok beġenen tanımadı̇̇ı bir yabancıysa onu kendi bilgisayarına kaydeder ve bugün harika bir resim çizdim diyerek paylașır. Ali ertesi gün okula geldiğinde arkadaşlanını çok güzel bir resim hakkında konuştuğunu fark eder. Yaklaşıp baktığında bunun kendi resmi olduğunu anlar. Arkadaşlarına sōyler ama kimse ona inanmaz. Ali çok üzgündür ve tanımadığı bu kişinin nasil olup da resmini aldığını merak etmektedir."

Sizce burada Ali gūvenli internet kullanımı ile ilgili öğrendiğiniz maddelerden hangisine dikkat etmemiştir? Ali’nin łaptığı hangi davranıștan dolayı dikkat etmediğini düşûndünüz?

Siz olsaydınız ne yapardınız?

2)"Ali okulda yaşadığı bu üzücü olaydan sonra eve gelir ve ödevlerini bitirdikten sonra biraz en sevdiği oyunla ilgili bir tartışma sitesindeki gelişmeleri okumaya karar verir. Oyundaki karakterlerden birinin oyuncağının satilık olduğunu görür ve hemen satan kișive mesaj atar. çok geçmeden cevap gelir oyuncağı satan kişi Ali’den kredi kartı bilgilerini ister. Ali ise kredi kartı olmadığını sōyler. Sonra satııı Ali’ye yaşını sorar ve Ali'nin kūçük olduğunu fark edince annesi ya da babasının cüzdanından kredi kartına ulaşabileceğini ve kart ile ilgili bilgilere nasıl ulașabileceğini anlatır. Ali annesi ve babası uyur uyumaz kredi kartını alır ve bilgileri gônderir..."

Sizce burada Ali gūvenli internet kullanımı ile ilg̈ili öğrendiğiniz maddelerden hangisine dikkat etmemiştir? Ali’nin yaptı́̆ı hangi davranıştan dolayı dikkat etmediğini düşūndünüz?

Siz olsaydiniz ne yapardınız? 
3) "Ali annesi ve babasına tüm arkadaṣlarının tatile gittiğini kendisinin de artık tatile gitmek istediğini anlatır. Annesi ve babası da iș yerlerinden izin alır almaz onların da gideceǧini açıklamaya çalı̧ıı Ali’ye. Ama Ali bu konuda sabırsızdır. Ailesinin tatile gitmek istemediğini onu oyaladığını düşünür ve üzülür. Sonra tabletini alıp bir köşeye çekilir ve en sevdiği çizgi filmi açmaya karar verir. Bu sırada çizgi filmi açmak için girdiği sitede "Bedava tatil kazandınız. Almak için tıklayın!" yazııını görūr ve sevinçle tıklar. Ancak bir şeyler ters gitmektedir. Tableti bir anda yavaşlamış sürekli yeni internet sayfaları açılmaya baṣlamışı̆ı..."

sizce burada Ali gũvenli internet kullanımı ile ilgili öğrendiğiniz maddelerden hangisine dikkat etmemiştir? Ali’nin yaptı̊̆ı hangi davranıștan dolayı dikkat etmediğini düşūndünüz?

siz olsaydinız ne yapardinız?

4) "Ali okulda arkadaşlarının kendisinden daha fazla Twitter'de takipçisi olduğunu duyar ve çok kıskanır. Eve gider gitmez Twitter a girer ve kendisine gelen tüm takipçi isteklerini tanısın tanımasın kabul eder. Arkadaşlarının takipçi sayıısını geçeceğini düșünüp mutlu olur."

Sizce burada Ali gũvenli internet kullanımı ile ilg̈ili öğrendiğiniz maddelerden hangisine dikkat etmemiştir? Ali'nin yaptı̇̆ı hangi davranıştan dolayıı dikkat etmediğini düşūndünüz?

Siz olsaydınız ne yapardınız?

5)"Ali internette bir sürü olumsuz şey yaşamıştır. Ancak bu durumu öğretmeni ya da ailesi ile paylaşmamıştır. Hepsini kendi başına halledebileceğini düşünmektedir."

Sizce burada Ali güvenli internet kullanımı ile ilgili öğrendiğiniz maddelerden hangisine dikkat etmemiştir? Ali’nin yaptı̆̆ı hangi davranıştan dolayı dikkat etmediğini düşündünüz?

Siz olsaydınız ne yapardınız? 


\section{Ek 4}

1) $2 * 2=$

2) $6+5=$

3) $8 / 2=$

4)15-7=

5) $20 * 8=$

$6) 15 / 3=$

Ek 5

1) $7 * 8=$

2) $9+5=$

3)19-8=

$4) 21 * 3=$

5) $2+1=$

6)3-0=

\section{Ek 6}

1) $5+2=$

2) $8 * 9=$

3) $11+15=$

4) $5+2 *(3-1)=$ 
5) $15 * 11=$

6) $25 / 5=$

7) $81 / 3=$

8) $7 * 12=$

9) $21+15=$

10) $23-19=$ 


\section{Ek 7}

Sınav kâğıtlarında öğrenenlerin hatırlamasının istendiği maddelerin her biri 20 puan olarak puanlanmıştır. Eğer iki özelliği içeren maddeler varsa özelliklerden birini hatırlamışsa 10 puan olacak şekilde değerlendirilmiştir. Alınabilecek en yüksek puan 100’ en düşük puan 0’dır.

\begin{tabular}{|l|l|}
\hline Madde & Puan \\
\hline $\begin{array}{l}\text { Eğer sosyal medya ortamlarını kullanıyorsanız } \\
\text { mutlaka paylaşımlarınızla ilgili gizlilik } \\
\text { ayarlarınızı kontrol edin. }\end{array}$ & \\
\hline $\begin{array}{l}\text { Kendinize ya da bir başkasına ait kişisel bilgileri } \\
\text { sosyal medya ortamlarında tanımadığınız kişilerle } \\
\text { paylaşmayınız. }\end{array}$ & \\
\hline $\begin{array}{l}\text { Web sayfalarında "Bedava ... Kazandınız!, } \\
\text { Kaçırılmaz Fırsat!, Deniz Kenarında Tatil Fırsatı" } \\
\text { vb. linklere tıklamayınız. }\end{array}$ & \\
\hline $\begin{array}{l}\text { Eğer sosyal medya ortamlarını kullanıyorsanız } \\
\text { sadece tanıdığınız kişilerden gelen arkadaşlık } \\
\text { isteklerini kabul edin. }\end{array}$ & \\
\hline $\begin{array}{l}\text { İnternet ortamında herhangi bir tehlikeyle } \\
\text { karşılaştı̆ı̆ınıı, kandırılddğınızı hissederseniz } \\
\text { mutlaka ailenizi veya öğretmeninizi bilgilendirin. }\end{array}$ & \\
\hline Toplam Puan & \\
\hline
\end{tabular}




\section{Ek 8}

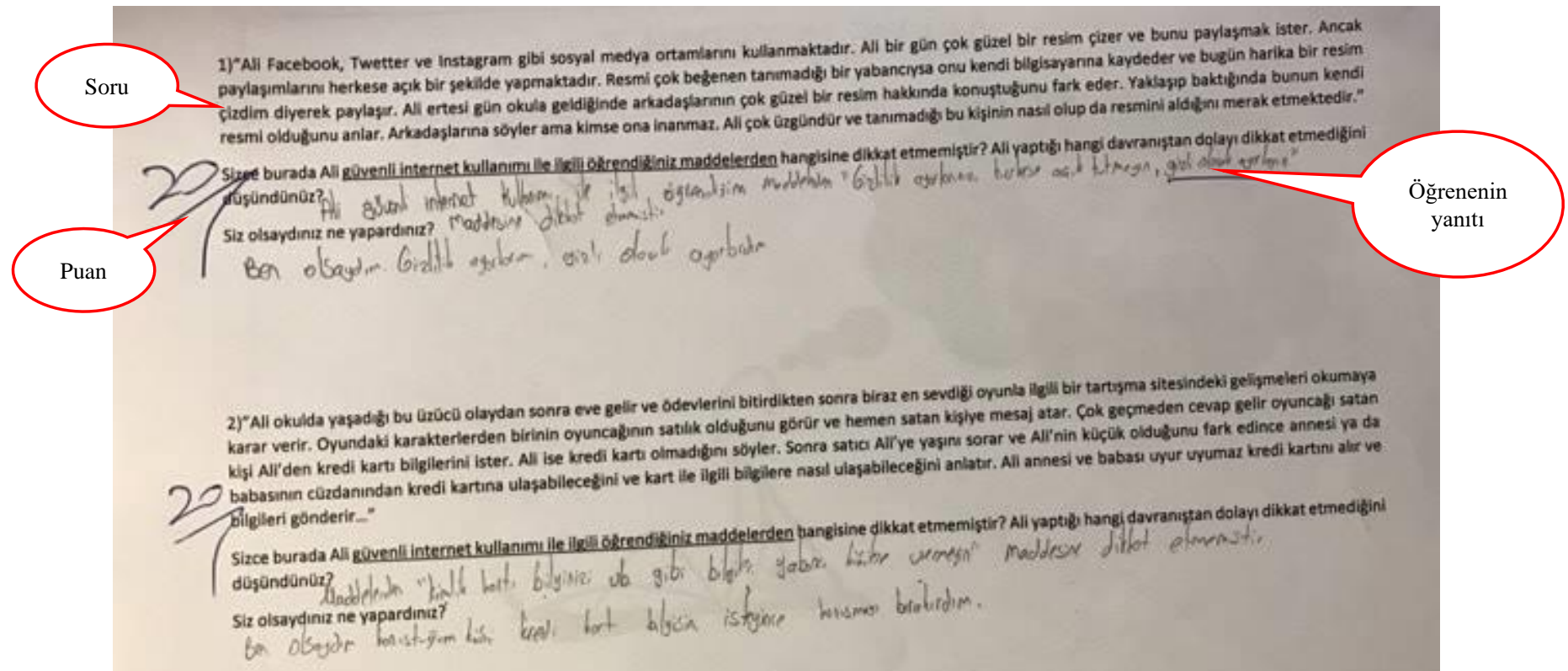

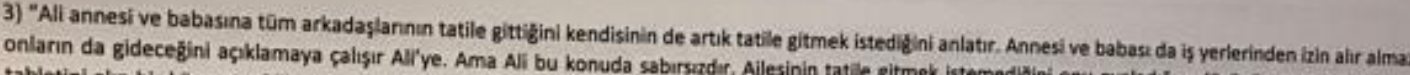
tabletini alıp bir köseye çekilir ve en sevdígi çizgi filmi açmaya karar verir. tıklayınl" yazısını görür ve sevinçle tikłar. Ancak bir ceyler ters gitmar verir, Bu sırada çizgi filmi açmak için girdigi sitede "Bedava tatil kazandinı. Almak ikin Sizce burada Ali gil düsündünüz? 20 sicolsaydiniz ne yapardiniz?

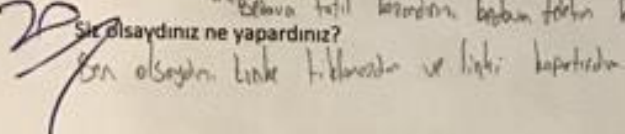

4) "Ali okulda arkadasłarinan kendisinden daha fazla twitterda takipcisi olduģunu duyar ve şok kskanir. Eve gider gitmez twitter a girer ve kendisine gelen tüm takipçi isteklerini tanısın tanımasın kabul eder. Arkadaşlannın takipci sayısinı geçecegini düsünüp mutlu olur:"

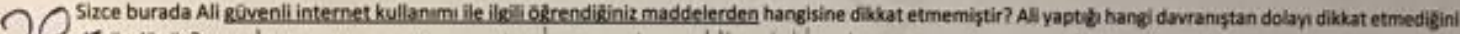

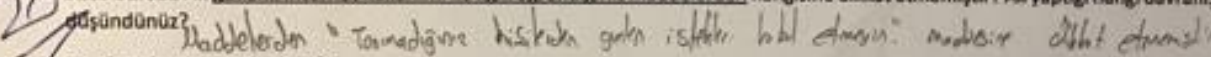
Siz olsaydiniz ne yapardiniz?

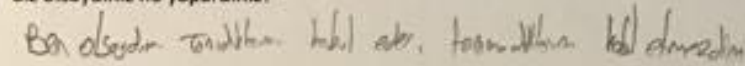




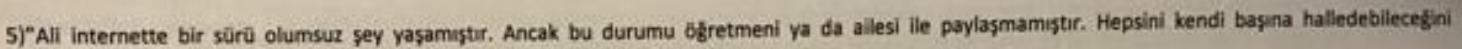
dușünmektedir:"

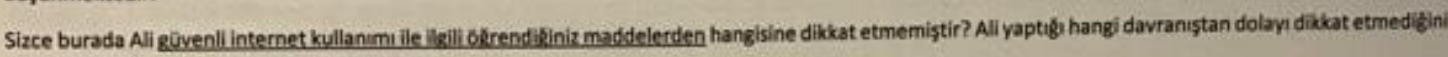
dōşūndūnlaz?

Siz olsaydinuz ne yapardiniz? 